\title{
Recent development of ATP-competitive small molecule phosphatidylinostitol-3-kinase inhibitors as anticancer agents
}

\author{
Yu Liu' ${ }^{1,2}$, Wen-zhu Wan ${ }^{1}$, Yan Li ${ }^{1}$, Guan-lian Zhou ${ }^{1}$ and Xin-guang Liu ${ }^{2}$ \\ ${ }^{1}$ School of Chemistry and Pharmaceutical Engineering, Qilu University of Technology, Jinan, P. R. China \\ ${ }^{2}$ Department of Hematology, Qilu Hospital, Shandong University, Jinan, P. R. China \\ Correspondence to: Xin-guang Liu, email: liuxingrant@163.com \\ Keywords: phosphatidylinostitol-3-kinase; PI3K; inhibitor; mTOR pathway; anticancer \\ Received: August 15, $2016 \quad$ Accepted: October 04, $2016 \quad$ Published: October 18, 2016
}

\begin{abstract}
Phosphatidylinostitol-3-kinase (PI3K) is the potential anticancer target in the PI3K/Akt/ mTOR pathway. Here we reviewed the ATP-competitive small molecule PI3K inhibitors in the past few years, including the pan Class I PI3K inhibitors, the isoform-specific PI3K inhibitors and/or the PI3K/mTOR dual inhibitors.
\end{abstract}

\section{INTRODUCTION}

The PI3K/AKT/mTOR signaling pathway (Figure 1) regulates diverse biological processes such as cell growth, cell proliferation, cell survival, protein synthesis, and glycolysis metabolism, which is frequently deregulated in human cancers [1-9]. PI3K (phosphatidylinostitol-3kinase) is the main anticancer target within this pathway, and its correlation with tumor-genesis, progression and maintenance has been validated by several extensive studies [10-20].

To date, a total of eight PI3Ks have been identified, which are divided into four classes (I, II, III and IV) based on their sequence homology. As the most relevant to the PI3K/Akt/mTOR pathway (Figure 1), Class I PI3Ks are always referred to as PI3Ks [21]. Generally, Class I PI3Ks are further divided into IA and IB based on their different regulatory subunits and upstream activators [22]. Class IA PI3Ks are activated by RTKs and GPCRs, which contains three isoforms (PI3K $\alpha, \mathrm{PI} 3 \mathrm{~K} \beta$ and $\mathrm{PI} 3 \mathrm{~K} \delta$ ) with the respective $\mathrm{p} 110$ catalytic subunit $(\mathrm{p} 110 \alpha, \mathrm{p} 110 \beta$, and $\mathrm{p} 110 \delta$ ) bound to the p85 regulatory subunit [21]. Class IB PI3K consists of PI $3 \mathrm{~K} \gamma$, with the $\mathrm{p} 110 \gamma$ bound to $\mathrm{p} 101$ or $\mathrm{p} 84$, which is mainly activated by GPCRs such as chemokine receptors [23]. PI3K $\alpha$ is known to play an important role in tumor genesis, which has been detected with persistent mutations and amplification in most human cancers including breast, ovarian, colorectal, stomach and gastric cancers [17, 24, 25]. PI3K $\beta$ involves in the development of thrombotic diseases by activating platelets, while PI $3 \mathrm{~K} \gamma$ and $\delta$ are the therapeutic targets of inflammatory and auto-immune diseases [22]. Beside $\mathrm{PI} 3 \mathrm{~K} \alpha$, the other three isoforms ( $\beta, \gamma$ and $\delta)$ are also involved in tumor genesis, especially in the case of PTEN loss or inactivation. Moreover, as PI3K mutation and PTEN inactivation have been shown to be the causes of resistance to other targeted cancer therapies [26], the PI3K may even circumvent drug resistance to current chemotherapy in combination with other anticancer drugs [27].

\section{THE DEVELOPMENT OF PI3K INHIBITORS}

The major PI3K inhibitors currently available are reversibly ATP-competitive. The X-ray crystal structure of PI3K [21] and those of its complexes with ATP, Wortmannin (1), LY294002 (3) [28, 29] and other diverse inhibitors facilitated and accelerated the development of PI3K inhibitors.

The binding models of inhibitors with the PI3K active site have also been generated in many recent studies. Overall, besides the solvent exposed area, the PI3K active site contains three key regions (PI3K $\gamma$, Figure 2) [30]: the hinge region (Val882), the affinity pocket (Lys833, Asp841, Tyr867, Ala885, Ser806, Tyr867) or the back pocket (DFG-motif, gate keeper and catalytic lysine) and the ribose pocket (Met804, Ala805, Lys802, Met953, Asp964, Trp812, etc.). Accordingly, the ATPcompetitive PI3K inhibitors mainly include (1) The hinge linker binder: substituents containing hydrogen donor/ acceptor to interact with Val882 ( morpholine, pyperazine, indole, quinolone, amine, methoxy group, etc.) (2) The affinity pocket moiety: hydrophobic side chains or heterocycles, that may contain hydrogen donor/acceptor (sulfonamide, urea, pyridine, indazole, pyrazole, carbonyl 
Table 1: Major PI3K inhibitors that have entered into clinical trials

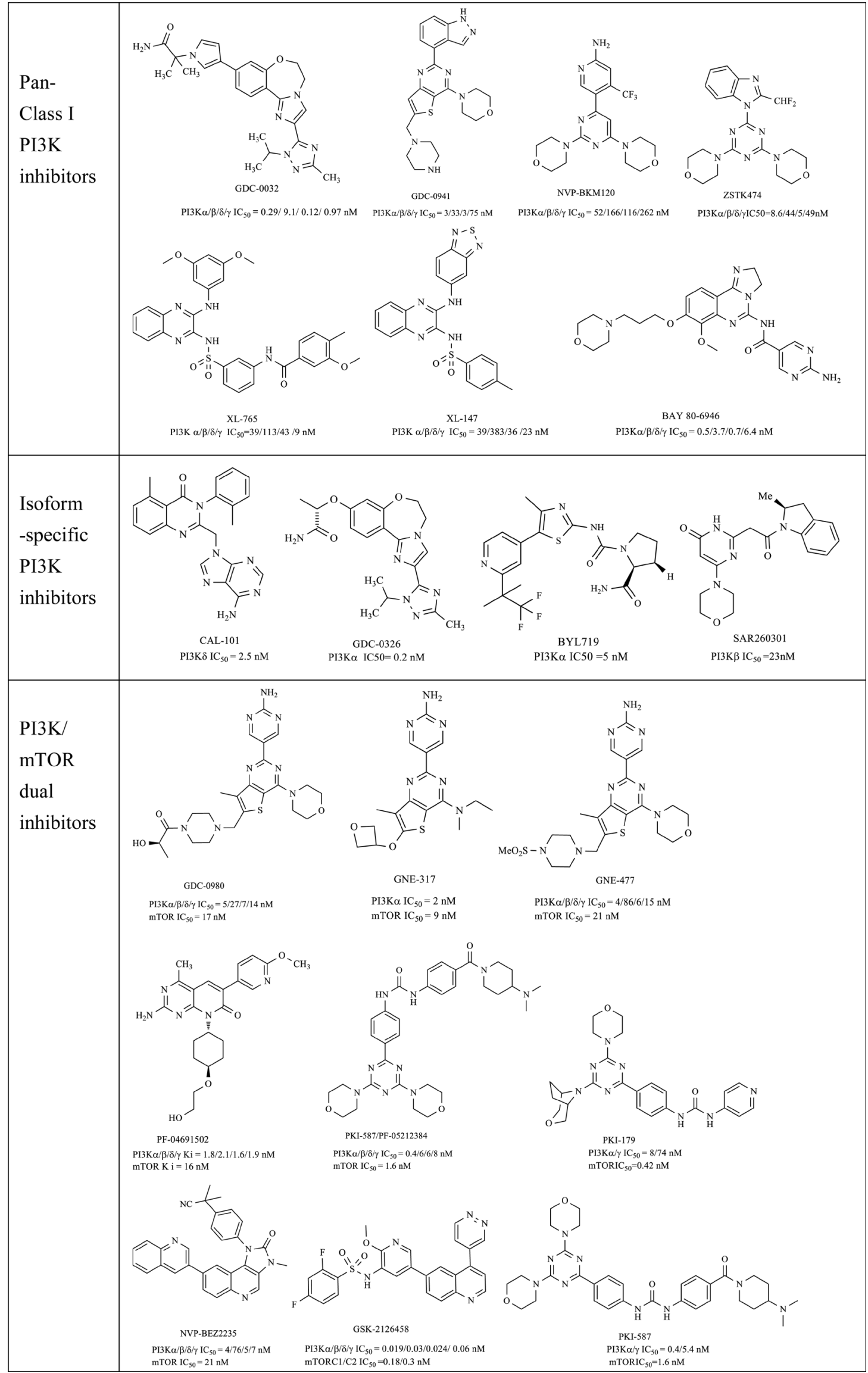


group, etc.) forming H-bonds with the residues directly or aided by a water molecule (3) The ribose pocket moiety: various substituted lipophilic ring systems and groups ( pyrrolidine, pyrimidine, morpholine, thiomethyl, etc.) (4) The central core, cyclic or bicyclic, with diverse structure, having no obvious effects on the potency of the inhibitors ( e.g., pyrimidine, quinazoline, pyridine, quinolone, indole, pyrazines, quinoxalines, triazoles, imidazoles, thiazoles, etc.). Of them, the hinge region binder is crucial for PI3K inhibitors, while the affinity pocket interaction could lead to improved potency and potential selectivity.

Driven by efforts in computer-based rational drug design and SAR (Structure-Activity Relationship) studies, numerous promising PI3K inhibitors have been developed and a dozen of them have entered clinical trials for treatment of cancer or other diseases (Table 1) [19]. The first approved PI3K inhibitor Idelalisib (Gilead Sciences, Inc., also known as CAL-101 and GS-1101), an orally bioavailable $\mathrm{PI} 3 \mathrm{~K} \delta$ selective inhibitor with high potency and selectivity $\left(\mathrm{p} 110 \delta \mathrm{IC}_{50}=2.5 \mathrm{nM}\right)$, was approved by the FDA in July 2014 for the treatment of several hematological malignancies, in combination with rituximab.

However, due to the high sequence homology of the catalytic domains and the conserved ATP-binding site, the key point for the development of PI3K inhibitors is to gain sufficient isoform- selectivity ( $\delta$ and/or $\gamma$ vs. $\alpha$ and $\beta$ ) and cross-kinase selectivity. Although it's not an easy task, the discovery of isoform-specific PI3K inhibitors were facilitated by the elucidation of the X-ray crystal structure of PI3K isoforms and those of its complexes with diverse inhibitors [27, 29, 30]. Additionally, because mTOR is PI3K-related kinase that has similar ATP site with PI3K, a number of PI3K inhibitors could also exhibit inhibitory activity against mTOR (PI3K/mTOR dual inhibitors), which may be more effective by delivering a powerful two-spot inhibition of the pathway and have the advantage of being less susceptible to PI3K drug resistance and

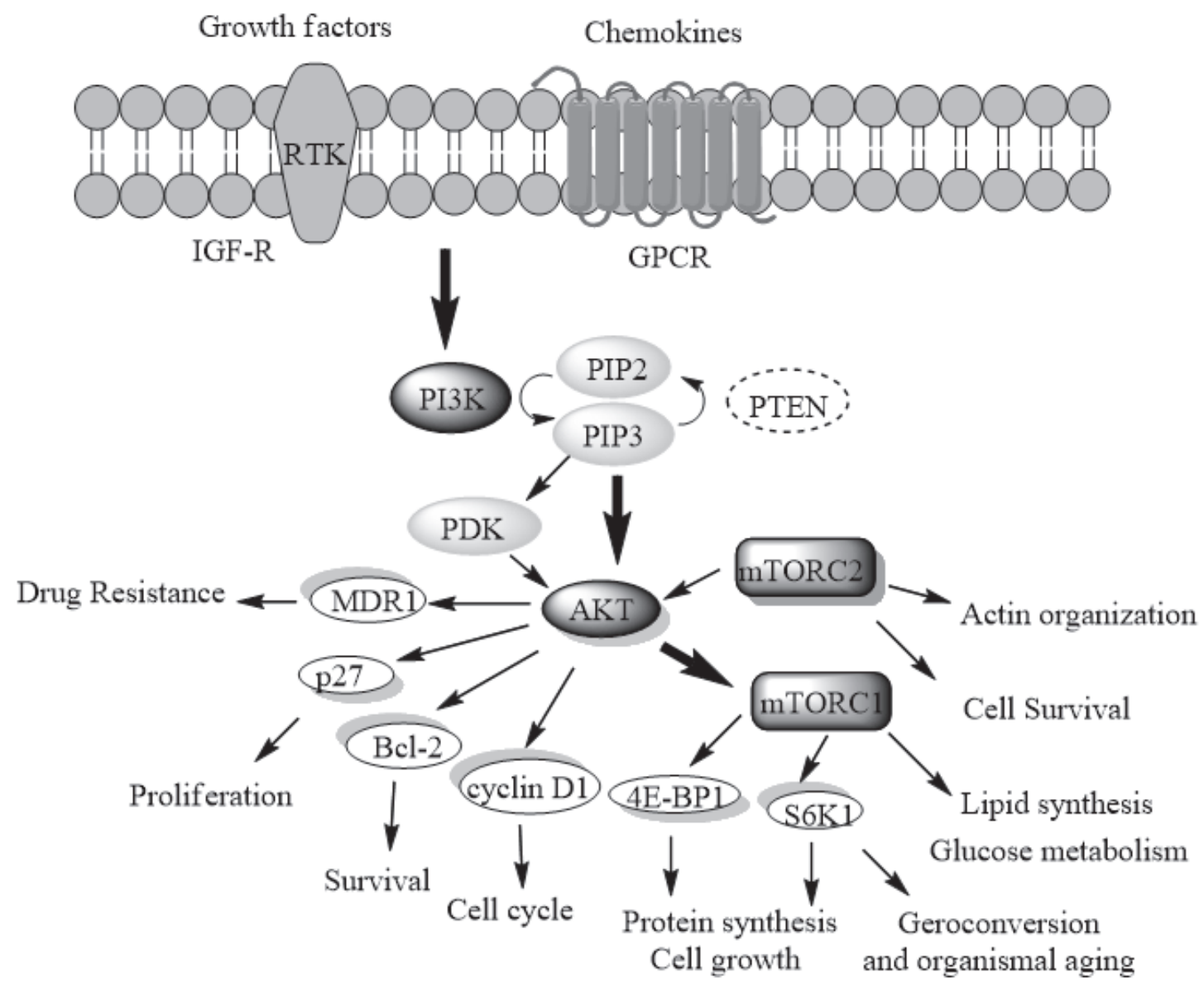

Figure 1: The PI3K/Akt/mTOR signaling pathway. Stimulation of this pathway is commonly triggered by the growth factors (e.g. IGF) or chemokine. Subsequent activation of the lipid PI3K leads to the phosphorylation of PIP2 to PIP3, which activates AKT and PDK1. Besides direct activation by PIP3, Akt could also be activated by PDK1 and mTORC2 (Rictor-mTOR). Then mTORC1 (Raptor-mTOR) was finally activated, which regulates cell growth, glucose and lipid metabolism, autophagy as well as protein synthesis, while mTORC2 regulates cell survival and actin reorganization. Additionally, the pathway is negatively regulated by PTEN. 
abrogating the compensatory effects of mTOR inhibitors [31]. In fact, most of the drug candidates in this area were PI3K/mTOR dual inhibitors (Table 1).

In this review we provide a recent view about the PI3K inhibitors including the pan PI3K inhibitors, the isoform- specific PI3K inhibitors and the PI3K/mTOR dual inhibitors, as anticancer drugs in the PI3K/Akt/ mTOR pathway. As there are many well-written reviews in this field before, the novel PI3K inhibitors we emphasized here are those developed in the past eight years. Based on their core structures, the inhibitors were divided into five series: natural product derivatives; pyrimidines and quinazolines; pyridines, quinolines and indoles; pyrazines and quinoxalines; azoles and others.

\section{NATURAL PRODUCTS DERIVATIVES}

Wortmannin (1), a steroidal furan derivative isolated from Penicillium wortmanni, was a pan PI3K inhibitor $\left(\mathrm{IC}_{50}\right.$ at $50 \mu \mathrm{M}$ ATP 4.0, 0.7, 4.1, $9.0 \mathrm{nM}$ for PI3K $\alpha, \beta, \delta$ and $\gamma$, respectively). At higher concentrations, it could also inhibit irrelevant kinases and PI3K-related kinases, such as mTOR, DNA-PK, and ATM.

The quercetin (2), a flavonoid, is a moderate pan PI3K inhibitor (PI3K $\alpha \mathrm{IC}_{50} \sim 3.8 \mu \mathrm{M}$ ). Diverse substitution of the chromone core of quercetin was studied and LY294002 (3), with a morpholine moiety replacement for the catechol ring, was identified by researchers at Lilly. Compound (3) was the first synthetic PI3K inhibitor $\left(\mathrm{PI} 3 \mathrm{~K} \alpha / \beta / \delta / \gamma \quad \mathrm{IC}_{50}=0.55 / 16 / 1.6 / 12 \mu \mathrm{M}\right)[32]$, which demonstrated chemical stability and improved selectivity against irrelevant kinase, while the selectivity towards class I PI3Ks, PI3K-related kinases was not so good.

To overcome the disadvantage of toxicity due to lack of selectivity, poor solubility, and low stability [33], derivatives with good pharmacodynamics were studied and PX-866 (4), the stable, furan-ring-opened derivatives of Wortmannin was thus identified $\left(\mathrm{PI} 3 \mathrm{~K} \alpha / \delta / \gamma \quad \mathrm{IC}_{50}=\right.$ 5.5/9.0/2.7 $\mathrm{nM}$ ), which is currently being evaluated in phase I/II trials for the treatment of patients with advanced solid tumors.

Aller et al [34] discovered that (-)-epigallocatechin3-gallate ( $5, \mathrm{EGCG}, \mathrm{Ki}=0.38,1.5,0.81,0.61$ and $0.32 \mu \mathrm{M}$ for PI3K $\alpha, \beta, \delta, \gamma$ and mTOR, respectively), a major component of green tea, as well as its related catechins including $\mathrm{CG}(6, \mathrm{Ki}=1.8 / 3 . / 3.2 / 0.91 / 0.14 \mu \mathrm{M}$, for PI3K $\alpha / \beta / \delta / \gamma$ and mTOR, respectively), ECG (7, Ki $=4.2 / 5.4 / 5.2 / 3.0 / 0.28 \mu \mathrm{M}$, for PI3K $\alpha / \beta / \delta / \gamma$ and $\mathrm{mTOR}$, respectively), $\mathrm{GCG}(8, \mathrm{Ki}=0.43 / 1.3 / 0.79 / 0.61 / 0.14$ $\mu \mathrm{M}$ for PI3K $\alpha / \beta / \delta / \gamma$ and mTOR, respectively) were all pan-PI3K/mTOR inhibitors. Molecular docking studies showed that EGCG was an ATP-competitive inhibitor of PI3K by binding well to the PI3K kinase domain active site.

Besides, many recent studies have demonstrated that a variety of natural products (or nutraceuticals) isolated from plants (e.g. fruits, vegetables, spices, nuts, legumes, herbs, etc.) also inhibit PI3K signaling, and exhibit potent anticancer activities. In 2013, Huang[35] briefly summarized that Apigenin, a family member of flavonoids, abundant in fruits (oranges, apples, cherries,grapes), vegetables (onions, parsley, broccoli, sweet green pepper, celery, barley, tomatoes)and beverages (tea, wine); Cryptotanshinone, one of the major tanshinones isolated from the roots of the plant Salviamiltiorrhiza Bunge (Danshen); Curcumin (diferuloylmethane), a polyphenol natural product of the plant Curcuma longa; Fisetin, a family member of flavonoids, occuring in fruits and vegetables( such as strawberries, apples, persimmons and onions); Indoles, natural compounds in cruciferous vegetables (such as broccoli, cauliflower, cabbage and brussels sprouts), especially indole-3-carbinol and it's in vivo dimeric product 3,3-diindolylmethane (DIM); Isoflavones, a class of flavonoid phenolic compounds, rich in soybean; Quercetin, a polyphenolic compounds, mainly from consumption of tea, onions, red grapes, and apples; Resveratrol, a natural polyphenol rich in red grapes and red wine; Tocotrienols, members of vitamin E superfamily; and many other natural products( such as caffeine, epigallocatechin gallate (EGCG, in green tea), celastrol (in traditional Chinese medicine named "Thunder of God Vine"), butein (in the stems of Rhus verniciflua, used as a food additive and as an herbal medicine in Asia), capsaicin (in chili peppers) and $\beta$-elemene (from the traditional Chinese medicinal herb Rhizoma zedoariae), etc.), have been reported to act as anticancer agents at least partly by inhibiting PI3K, Akt or mTOR activity.

\section{PYRIMIDINES AND QUINAZOLINES}

The pyrimidine containing PI3K inhibitors have always been the most interesting area, which include most of the clinical candidates, such as GDC-0941(13), PKI402(55), GNE-477 (66), BKM-120(90), PI-103(102), GDC-0980(107), and PF-04691502 (122), PF-06465603 (124) PF-04979064 (127). Most of the compounds in this series are PI3K/mTOR dual inhibitors, while a few exhibited PI3K isoform or kinase selectivities, which is the major goal of the development of the PI3K inhibitors currently.

In 2008, series of thieno [3, 2-d] pyrimidine derivatives were prepared and evaluated as inhibitors of PI3K p110 $\alpha$ by Folkes et al [36]. The lead (9) was reported as a potent PI $3 \mathrm{~K} \alpha$ inhibitor, but with poor pharmacokinetic profile. Derivatives with substitution of 6-positions (10) and the replacement of phenol group (11) were synthesized. Indazoles(12) as the replacements of phenols serve as a hydrogen bond donor with Tyr836, while reduced glucuronidation and resulted in acceptable oral bioavailability. This resulted in the discovery of GDC-0941(compound 13, PI3K $\alpha / \beta / \delta / \gamma \mathrm{IC}_{50}=3 / 3.3 / 3 / 7.5$ $\mathrm{nM}$, mTOR $\left.\mathrm{IC}_{50}=0.58 \mu \mathrm{M}\right)$, a potent, selective, orally 
bioavailable inhibitor of Class I PI3K including the p110 $\alpha$ mutant enzymes, and is currently being evaluated in human clinical trials for cancer treatment.

In 2009, series of morpholine-containing pyrazolopyrimidine analogues were synthesized and evaluated by Zask et al [37]. The optimization of compound $14\left(\mathrm{PI} 3 \mathrm{~K} \alpha \mathrm{IC}_{50}=47 \mathrm{nM}, \mathrm{mTOR} \mathrm{IC}_{50}=9.6 \mathrm{nM}\right)$ including the phenol group bioisosteres (15), piperidine ring substituents (16) and urea analogues (17), led to the discovery of potent mTOR kinase inhibitors (mTOR IC $\sim 0.08-2450 \mathrm{nM})$ with great selectivity $(\sim 5-1500$ fold $)$ versus PI3K $\alpha\left(\mathrm{PI} 3 \mathrm{~K} \alpha \mathrm{IC}_{50} \sim 6-2000 \mathrm{nM}\right)$.

Then they [38] investigated the effects of morpholine substitution on the potency and selectivity of pyrazolopyrimidines (18-21) by incorporating chiral, achiral methyl substituted morpholines and bridged morpholines (22-29). The result showed that these chiral morpholines led to potent mTOR inhibitors (mTOR IC $\sim 0.1-100 \mathrm{nM})$ with great selectivity $(\sim 32-20000$ fold $)$ versus PI3K $\alpha\left(\mathrm{PI} 3 \mathrm{~K} \alpha \mathrm{IC}_{50} \sim 35-9000 \mathrm{nM}\right)$. Molecular modeling [38] suggested that a leucine for phenylalanine substitution in mTOR versus PI3K in the hinge regions led to a deeper pocket in mTOR relative to PI3K that could better accommodate the steric bulk of the bridged morpholine.

Meanwhile, Verheijen et al [39] in the same team synthesized a series of 4-morpholino- 6-aryl -1H-pyrazolo $[3,4-\mathrm{d}]$ pyrimidines (30-33) (mTOR $\mathrm{IC}_{50} \sim 0.3-500 \mathrm{nM}$, PI3K $\alpha$ IC $_{50} \sim 14-2000 \mathrm{nM}$ ) as mTOR inhibitors, while some 6-ureidophenyl substituents (34) led to potent dual inhibitors of mTOR and PI3K $\alpha$ ( selectivity $\sim 0.4-3000$ fold).

Liu et al [40] in Pfizer discovered 4-methylpteridinones (36) as orally active and selective $\mathrm{PI} 3 \mathrm{~K} / \mathrm{mTOR}$ dual inhibitors $(\mathrm{PI} 3 \mathrm{~K} \alpha \mathrm{Ki} \sim 2-82 \mathrm{nM}$, mTOR Ki 0.85-3940 nM), with non-selective inhibitor 2-aminopyridopyrimidinone (35) as the lead. The 4-methylpteridinones were designed based on a small special pocket within PI3K and mTOR binding pocket to improve selectivity against other kinases, which was to be able to accommodate the methyl group of compound 37 and 38. Series of compounds (e.g. 39) with excellent selectivity for PI3K and mTOR were discovered. In addition, small changes in the C-6 aryl group will have profound effects on either PI3K or mTOR potency.

Nowak et al [41] reported the identification and optimization of pyrazolopyrimidines as mTOR kinase inhibitors (41-43, mTOR $\mathrm{IC}_{50} \sim 4-7300 \mathrm{nM}, \mathrm{PI} 3 \mathrm{~K} \alpha$ $\left.\mathrm{IC}_{50} \sim 31-6000 \mathrm{nM}\right)$. The lead (40, $\mathrm{mTOR} \mathrm{IC}_{50}=215 \mathrm{nM}$, $\mathrm{PI} 3 \mathrm{~K} \alpha \mathrm{IC}_{50}=36 \mathrm{nM}$ ), a PI3K/ mTOR dual inhibitor, was identified by high throughput screening (HTS). Finally, a potent and selective mTOR inhibitor $44\left(\mathrm{mTOR}^{\mathrm{I}} \mathrm{IC}_{50}=9\right.$ $\mathrm{nM}, \mathrm{PI} 3 \mathrm{~K} \alpha \mathrm{IC}_{50}=1962 \mathrm{nM}$ ) was discovered.

Malagu et al [42] discovered a novel series of mTOR kinase inhibitors $(45,46)$, but the PI3K inhibitory activity was not revealed, except that of compound 47 , which was $8.9 \mu \mathrm{M}$ against PI3K $\alpha, 1000$ - fold less potent than that against mTOR.

In 2010, Chen et al [10] reported a series of 4-morpholinopyrrolopyrimidine derivatives as PI3K inhibitors, by the modification of compound 48, an imidazolopyrimidine derivative with good PI3K $\alpha$ activity $\left(\mathrm{PI} 3 \mathrm{~K} \alpha \mathrm{IC}_{50}=63 \mathrm{nM}\right)$. Followed by modification on the N5 of the imidazole ring, the 3-hydroxyl group on the phenyl ring and the N7 position (49-50), 4-ureidobenzamide derivatives with extended amino groups (51-53) were synthesized with excellent cell potency. As the most potent compound, $54\left(\mathrm{PI} 3 \mathrm{~K} \alpha \mathrm{IC}_{50}=0.9 \mathrm{nM}\right.$, mTOR $\mathrm{IC}_{50}$ $=0.6 \mathrm{nM}$ ) also demonstrated in vivo antitumor efficacy. The replacement of the 3-hydroxy methyl group with 4-arylurea is outstanding, which not only improved metabolic stability but also increased enzyme potency and cell potency [7] .

Dehnhardt et al [31] described the discovery of PKI-402 (55, PI3K $\alpha / \beta / \delta / \gamma \quad \mathrm{IC}_{50}=1 / 7 / 14 / 16 \mathrm{nM}, \mathrm{mTOR}$ $\left.\mathrm{IC}_{50}=1.7 \mathrm{nM}\right)$, a novel dual PI3K/mTOR inhibitor. With imidazole- -pyrimidine $56\left(\mathrm{PI} 3 \mathrm{~K} \alpha / \gamma \mathrm{IC}_{50}=45 / 1134 \mathrm{nM}\right.$, $\mathrm{mTOR}$ IC50 $=634 \mathrm{nM}$ ) as the lead, triazolopyrimidine $57\left(\mathrm{PI} 3 \mathrm{~K} \alpha / \gamma \mathrm{IC}_{50}=83 / 435 \mathrm{nM}, \mathrm{mTOR} \mathrm{IC}_{50}=250 \mathrm{nM}\right)$, arylureido and 4-benzamidoureido analogues (58-59) were synthesized and evaluated. Compound 56 was identified, with excellent potency in vitro and in vivo, good physical properties and pharmacokinetic parameters.

Pecchi et al [43] identified 2-morpholino 6-(3-hydroxyphenyl) pyrimidine $\left(60, \mathrm{PI} 3 \mathrm{~K} \alpha \mathrm{IC}_{50}=0.031\right.$ $\mu \mathrm{M})$ as a potent and selective PI3K inhibitor initially, then analogues of 2, 4, 6-trisubstituted pyrimidine (6163 ) were prepared by solid phase synthesis and evaluated $\left(\mathrm{PI} 3 \mathrm{~K} \alpha \mathrm{IC}_{50}=0.031-16 \mu \mathrm{M}\right)$, which were approximately equipotent against $\alpha$ and $\delta$ isoforms, while about 10 -fold less potent against the $\beta$ and $\gamma$ isoforms.

Heffron et al [44] (Genentech) discovered that, 2-aminopyrimidine derivatives replacing indazole moiety of GDC-0941 (13, PI3K $\left.\alpha / \mathrm{mTOR} \mathrm{IC}_{50}=3 / 580 \mathrm{nM}\right)$, exhibited improved mTOR inhibition and improved potency while maintaining PI3K $\alpha$ inhibition. This finding was an entry into the identification of many attractive $\mathrm{PI} 3 \mathrm{~K} / \mathrm{mTOR}$ dual inhibitors. Modification in the 6- and 7- position (64-65) of the thienopyrimidine core resulted in comparable potency ( $\mathrm{IC}_{50} \sim 1-7 \mathrm{nM}$ and $29-59 \mathrm{nM}$ for PI3K and mTOR, respectively). The 7- methyl group was introduced to disrupt planarity and improve clearance in vivo. This led to the identification of GNE-477 (66, $\mathrm{PI} 3 \mathrm{~K} \alpha / \beta / \delta / \gamma \mathrm{IC}_{50}=4 / 86 / 6 / 15 \mathrm{nM}, \mathrm{mTOR} \mathrm{IC}_{50}=4 / 21$ $\mathrm{nM}$ ), a potent dual PI3K/mTOR inhibitor with desirable pharmacokinetic properties.

Zask and Verheijen et al (Wyeth) previously reported [38] that bridged morpholines on pyrazolopyrimidine(67) and thienopyrimidine (68) scaffolds with aparaureidophenyl substituent led to potent mTOR inhibitors with greater selectivity for mTOR versus PI3K than the corresponding morpholine containing analogs. 
They introduced the ethylene-bridged morpholine, and 4-ureidophenyl groups substituent in 4-morpholinothieno [3, 2-d] pyrimidines [45] (e.g., compound 69 and 70, moderate PI3K/mTOR dual inhibitors), which led to highly potent $\mathrm{mTOR}$ inhibitors $\left(\mathrm{IC}_{50} \sim 0.29-100 \mathrm{nM}\right)$ with good selectivity (up to $>1000$-fold) over PI3K $\alpha\left(\mathrm{IC}_{50} \sim 8.3\right.$ $10000 \mathrm{nM})$.

In 2010, they extended these discoveries to other scaffolds, including thienopyrimidine (71-73) and triazine (74-76) scaffold. And then, bridged morpholines (26-29) were incorporated in monocyclic triazine PI3K/mTOR inhibitors [46], and compounds with ureidophenyl groups (76) gave highly potent and selective mTOR inhibitors $\left(\mathrm{IC}_{50} \sim 0.5-130 \mathrm{nM}\right)$ over PI3K $\alpha\left(\mathrm{IC}_{50} \sim 24-3438 \mathrm{nM}\right)$, as expected.

Sutherlin et al [47] (Genentech) discovered (thienopyrimidin-2-yl) amino pyrimidines (77-78) as panPI3K and pan-PI3K/mTOR dual inhibitors. Structural modification of the GDC-0941 (13, a pan-PI3K inhibitor, $\mathrm{IC}_{50}=3 / 33 / 3 / 66 / 580 \mathrm{nM}$ for PI3K $\alpha / \beta / \delta / \gamma$ and mTOR, respectively) resulted in compound (79), a potent pan-PI3K/mTOR dual inhibitor $\left(\mathrm{IC}_{50}=3.4 / 12 / 16 / 16 / 30\right.$ $\mathrm{nM}$ for $\mathrm{PI} 3 \mathrm{~K} \alpha / \beta / \delta / \gamma$ and $\mathrm{mTOR}$, respectively). The increased mTOR potency was presumably caused by the aminopyrimidine group, which was adjacent to Asp836 (PI3K $\gamma$ )/ Glu2190 (mTOR), and the Glu2190 was more flexible than Asp836. Then compound (80) was designed, with 4-methyl group added on the aminopyrimidine, and lacked mTOR inhibitory activity $\left(\mathrm{IC}_{50}=3.5 / 25 / 5.2 / 15 /\right.$ $750 \mathrm{nM}$ for PI3K $\alpha / \beta / \delta / \gamma$ and mTOR, respectively). The crystal structure showed that [47] this selectivity was due to the 4-methyl group, which twisted the amino pyrimidine ring out of the plane of the thienopyrimidine, and pointed toward the upper surface of the binding pocket where differences in mTOR and PI3K exist.

Venkatesan et al [48] reported a series of novel 2-aryl or heteroaryl substituted-4-morpholino imidazolopyrimidine derivatives (81-82) as moderate to potent dual PI3K/mTOR inhibitors (PI3K $\alpha \mathrm{IC}_{50} \sim 11$ $189 \mathrm{nM}, \mathrm{PI} 3 \mathrm{~K} \gamma \mathrm{IC}_{50} \sim 47-10000 \mathrm{nM}, \mathrm{mTOR} \mathrm{IC}_{50} \sim 51-$ $7200 \mathrm{nM}$ ), which had good tumor cell growth inhibition and suppression of pathway specific biomarkers such as phosphorylation of Akt.

In 2011, Burger et al (Novartis) [49] discovered a series of 2-morpholino, 4-substituted, 6-heterocyclic morpholino pyrimidines (84-86, PI3K $\alpha \mathrm{IC}_{50} \sim 2-7740$ $\mathrm{nM}$ ) as potent PI3K inhibitors. The lead compound 83 was a potent pan class I PI3K inhibitors (PI3K $\alpha \mathrm{IC}_{50} \sim 50$ $\mathrm{nM}$ ) with poor pharmacokinetic properties due to the phenol group. Then the C6 phenol moiety was replaced by diverse heterocycles, and the aminopyridine turned to be the best choice, being equipotent to the phenol. After the $\mathrm{C} 4$ position was further optimized, pharmacokinetic and efficacy study conducted, compound 87 (PI3K $\alpha \mathrm{IC}_{50}$ $<2 \mathrm{nM}$ ) was identified with efficacy and suitable in vivo pharmacokinetic properties.

Then in their continued study [50], C4'modified, C6 pyridyl or pyrimidyl substituted 2-morpholino 4-aminoquinolyl pyrimidines (88) were synthesized and evaluated, aiming to improve potency and reduce

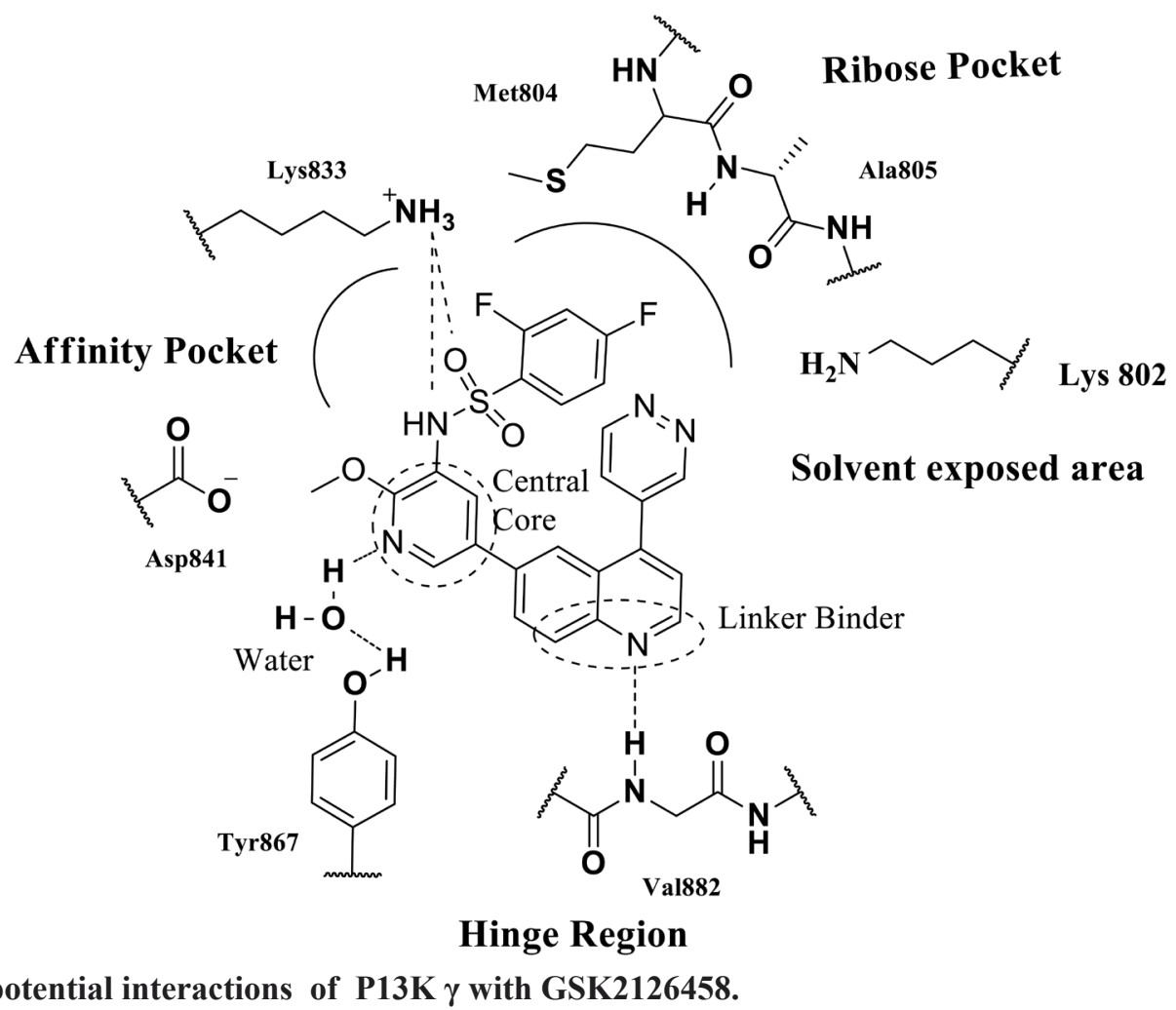

Figure 2: The potential interactions of P13K $\gamma$ with GSK2126458. 
the in vivo CL values. "Incorporation of a morpholine group at the $\mathrm{C} 4$ position increased the aqueous solubility while maintaining potency, selectivity, and in vivo properties". This led to the discovery of substituted 6-aminoheterocyclic 2, 4-bis morpholino pyrimidines (89), of which the highest soluble and the most potent compound was compound 90 (NVP-BKM120, PI3K $\alpha$ $\left.\mathrm{IC}_{50} \sim 30 \mathrm{nM}, \mathrm{mTOR} \mathrm{IC}_{50} \sim 4600 \mathrm{nM}\right)$ that has entered into Phase II clinical trials for the treatment of cancer.

In the design of $\mathrm{PI} 3 \mathrm{~K} / \mathrm{mTOR}$ inhibitors from pyrido[2.3-d]pyrimidin- 7-one (91) and pteridinone (92), Liu et al (Pfizer) [51] introduced intra-molecular hydrogen bonding to the quinazoline motif to form a pseudo ring (intra-molecular H-bond scaffold, iMHBS), which was confirmed by the initial compound 94 (PI3K $\alpha \mathrm{Ki}=18 \mathrm{nM}$, mTOR $\mathrm{Ki}=416 \mathrm{nM})$ and $95(\mathrm{PI} 3 \mathrm{~K} \alpha \mathrm{Ki}=26 \mathrm{nM}, \mathrm{mTOR}$ $\mathrm{Ki}=13 \mathrm{nM})$. This design resulted in potent PI3K/mTOR dual inhibitors $(93, \mathrm{PI} 3 \mathrm{~K} \alpha \mathrm{Ki}$ up to $0.3 \mathrm{nM}$, mTOR Ki up to $3 \mathrm{nM})$.

Heffron et al (Genentech) [52] described two chemical series achieving $\mathrm{PI} 3 \mathrm{~K} \alpha$ selectivity versus PI3K $\beta$, which could be explained using homology model of $\mathrm{PI} 3 \mathrm{~K} \beta$. In the thienopyrimidine series $(96, \mathrm{PI} 3 \mathrm{~K} \alpha \mathrm{Ki}$ $\sim 0.4-47 \mathrm{nM}, \mathrm{PI} 3 \mathrm{~K} \beta \mathrm{Ki} \sim 7-1167 \mathrm{nM})$, the selectivity (e.g. 98 and 99) was derived from "a hydrogen bonding with Arg770 of $\mathrm{PI} 3 \mathrm{~K} \alpha$ that is not attained with the corresponding Lys777 of PI3K $\beta$ ". In the benzoxepine series (97), the selectivity (e.g. 100 and 101) was due to the "electrostatic potential differences between the two isoforms in a given region".

Using PI-103 (102) as the lead, Large et al [53] designed two series of trisubstituted pyrimidines, 3-hydroxyphenol analogues (103-104) and bioisosteric replacements (105), as PI3K inhibitors. The 3-phenolic motif was replaced by three surrogate types (A, B and $\mathrm{C})$, to avoid the glucuronidation in vivo. The most potent inhibitor was 6-aryl substitution compound 106 (PI3K $\alpha$ $\mathrm{IC}_{50}=62 \mathrm{nM}$ ), with similar activity against PI3K $\beta$ and $\delta$. All three surrogate types had metabolic stabilities and inhibitory activity similar to those of parent phenols.

Sutherlin et al (Genentech) [54] reported the discovery of GDC-0980 (107), a potent, selective, and orally available class I PI3K/ mTOR inhibitor (PI3K $\alpha / \beta /$ $\delta / \gamma \mathrm{IC}_{50}=5 / 27 / 7 / 14 \mathrm{nM}$, mTOR Ki $\left.=17 \mathrm{nM}\right)$, modified from the class I PI3K inhibitor GDC-0941(13). The 2-aminopyrimidine substitution for the indazole (108) increased potency for mTOR by 20 -fold. A methyl group was then added to the thienopyrimidine core (109) to lower the in vivo clearances and a lactic amide was used to replace sulfonamide to increase the solubility. This compound had entered clinical trials for cancer.

In 2012, Finlay et al (AstraZeneca) [55] described a high throughput screening approach to identify ATP competitive mTOR kinase inhibitors, starting with a modestly potent inhibitor sulfonyl morpholinopyrimidine $110\left(\mathrm{mTOR} \mathrm{IC}_{50}=1.41 \mu \mathrm{M}, \mathrm{PI} 3 \mathrm{~K} \alpha \mathrm{IC}_{50}=17.3 \mu \mathrm{M}\right)$.
Variation of substituents at the pyrimidine 2, 4, 6 position (111) provided compounds with higher mTOR potency $\left(\mathrm{mTOR} \mathrm{IC}_{50}=0.02-100 \mu \mathrm{M}, \mathrm{PI} 3 \mathrm{~K} \alpha \mathrm{IC}_{50}=0.56-300 \mu \mathrm{M}\right)$. The urea derivatives such as 112 , exhibited the highest mTOR enzyme potency and also retained selectivity against $\mathrm{PI} 3 \mathrm{~K} \alpha \quad\left(\mathrm{mTOR} \mathrm{IC}_{50}=0.028 \mu \mathrm{M}, \mathrm{PI} 3 \mathrm{~K} \alpha \mathrm{IC}_{50}=\right.$ $0.565 \mu \mathrm{M}$ ), which confirmed that the [4-(4-morpholin4-yl pyrimidin-2-yl) phenyl] urea motif was a privileged scaffold for mTOR and PI3K inhibition.

Koehler et al (Genentech) [56] designed and synthesized a novel class of potent, highly selective mTOR kinase inhibitors based upon saturated heterocycles fused to a pyrimidine core. The lead was morpholino thienopyrimidine (113), a potent mTOR inhibitor (mTOR $\mathrm{Ki}=3 \mathrm{nM}, 20$-fold selective over PI3K). In an effort to improve the solubility and metabolic stability, by replacing the thiophene with a saturated ring, the pyrrolopyrimidines (115), 6-aza-tetrahydroquinazoline (116), 7-aza-tetrahydro quinazoline compound (117-118) were synthesized and evaluated (mTOR Ki $=1.3 \sim 1500 \mathrm{nM}$, PI3K $\alpha \mathrm{Ki}=6.5 \sim$ $>1000 \mathrm{nM}$ ). The result showed that the compound (114), with the phenyl ethyl urea and s-methyl morpholine hinge binder, exhibited nanomolar potency and high selectivity against PI3K and other kinases.

A novel series of 4-methylpyrido pyrimidinone (MPP) were discovered as PI3K $\alpha / \mathrm{mTOR}$ dual inhibitors by Le et al (Pfizer) [57]. The lead compound (119, PI3K $\alpha$ $\mathrm{Ki}=1.56 \mathrm{nM}$, mTOR $\mathrm{Ki}=142 \mathrm{nM}$ ) was potent, while had poor solubility and moderate lipophilic efficiency. Then through "integration of SBDD and physical properties based optimization", a series of analogs were designed (120, PI3K $\alpha \mathrm{Ki}=12.5 \sim 138$ nM, mTOR Ki = 10.6 663 $\mathrm{nM})$. Notably, MPP derivative (121), with a pyrazole head piece and pyrrolidinyl, exhibited good potency (PI3K $\alpha \mathrm{Ki}$ $=12.5 \mathrm{nM}$, mTOR Ki $=10.6 \mathrm{nM}$ ), desirable stability and oral bioavailability.

PF-04691502 (122), a 4-MPP derivative, exhibited potent activity against $\mathrm{PI} 3 \mathrm{~K}$ and $\operatorname{mTOR}(\mathrm{PI} 3 \mathrm{~K} \alpha \mathrm{Ki}=$ $0.57 \mathrm{nM}$, mTOR $\mathrm{Ki}=16 \mathrm{nM}$ ), while "modeling studies revealed that there was still space between the terminal alcohol and the polar residues of a solvent exposed region, and no $\mathrm{H}$ bond interaction between $\mathrm{MeO}$-pyridine and Lys 833". Then Cheng et al (Pfizer) [58] designed the MPP derivatives (123) with different heteroaryl groups in the 6 position, with cis or trans- cyclohexyl in the 8 position and with a terminal alcohol, a carboxylic acid or a carboxyl amide. These compounds (123) retained potent activity (PI3K $\alpha \mathrm{Ki} \sim 0.31-26.4 \mathrm{nM}$, mTOR Ki 4.42-92.6 nM). $\mathrm{PF}-06465603$ (124, PI3K $\alpha \mathrm{Ki}=0.35 \mathrm{nM}, \mathrm{mTOR} \mathrm{Ki}=$ $8.63 \mathrm{nM}$ ), a metabolite of PF-04691502 with a terminal carboxylic acid, was identified.

In their search for a structurally differentiated backup candidate to PF-04691502 (122, PI3K $\alpha \mathrm{Ki}=0.57$ $\mathrm{nM}$, mTOR Ki=16 nM), compound (125), a tricyclic imidazo [1,5] naphthyridine, was identified as potent $\mathrm{PI} 3 \mathrm{~K} / \mathrm{mTOR}$ inhibitor $(\mathrm{PI} 3 \mathrm{~K} \alpha / \mathrm{mTOR} \mathrm{Ki}=1.41 / 4.51$ 
$\mathrm{nM}$ ), while has poor solubility, and high metabolic clearance [59]. Then tricyclic derivatives (126) were synthesized through integration of SBDD and PPBO (Physical properties-based optimization), and the most suitable compound, PF-04979064 (127, PI3K $\alpha / \gamma / \delta \mathrm{Ki}$ $=0.130 / 0.111 / 0.122 \mathrm{nM}$, mTOR Ki $=1.42 \mathrm{nM})$, was discovered as a backup candidate to PF-04691502.

Leahy et al [60] disclosed a novel series of potent and selective PI3K $\gamma$ inhibitors (131-136), based on hits 128 and 129, which were identified from HTS of $\sim 4.6$ million compounds. The sulfonyl piperazine series (131) of hit 128 had improved potency and selectivity, while with poor pharmacokinetic properties. The screening of hybrid sulfonamide derivatives (132-136) of hit 129 , provided a series of promising leads with suitable pharmacokinetic properties (e.g., $130, \mathrm{PI} 3 \mathrm{~K} \alpha / \beta / \delta / \gamma \mathrm{IC}_{50}=$ 435/ 2059/ 690/18 nM).

Lee et al [61] identified imidazolopyrimidine (137) as a modestly potent $\mathrm{mTOR}$ inhibitor $(\mathrm{mTOR} \mathrm{Ki}=72 \mathrm{nM}$, $\mathrm{PI} 3 \mathrm{~K} \alpha \mathrm{Ki}=2 \mathrm{nM}$ ) by a HTS. To increase mTOR potency and selectivity over PI3Ks, they replaced the morpholine/ aminopyrimdine of (137) with (S)-3-methyl-morpholine / ethyl phenyl urea to provide a more potent and selective mTOR inhibitor $(138$, mTOR $\mathrm{Ki}=72 \mathrm{nM}$, PI3K $\alpha \mathrm{Ki}$ $=190 \mathrm{nM})$. Using (138) as the lead, a variety of N-9-Meimidazolopyrimidines (139, mTOR Ki $=7-12 \mathrm{nM}, \mathrm{PI} 3 \mathrm{~K} \alpha$ $\mathrm{Ki}=370-390 \mathrm{nM})$; N-7-Me- imidazolopyrimidines(140, mTOR Ki $=4-150 \mathrm{nM}$, PI3K $\alpha \mathrm{Ki}>5000 \mathrm{nM}$ ); N-5-Mepyrrolo[3,2-d] pyrimidines(141, mTOR Ki = 6-19nM, PI3K $\alpha$ Ki $>3000 \mathrm{nM}$ ), and N-1-Me-pyrazolo [4,3d] pyrimidines $(142$, mTOR Ki $=1-28 \mathrm{nM}, \mathrm{PI} 3 \mathrm{~K} \alpha \mathrm{Ki}$ $>3000 \mathrm{nM}$ ) were synthesize and evaluated for mTOR inhibition and selectivity against PI3K.

In 2014, Han et al [62] identified structurally novel and potent $\mathrm{PI} 3 \mathrm{~K} / \mathrm{mTOR}$ dual inhibitors from a series of 2-amino-4-methylpyrido [2, 3-d] pyrimidine derivatives (145-147). As indicated by the crystal structure of PF04691502 (122, PI3K $\alpha / \mathrm{mTOR} \mathrm{Ki}=0.57 / 16 \mathrm{nM})$ and GSK2126458 (143) docked into PI3K $\gamma$, the aminopyridopyrimidinone and quinoline formed critical hydrogen bonds with Val 882 in the hinge region. The aminopyrimidine (144) was initially synthesized and demonstrated modest inhibitory activity (PI3K $\alpha / \mathrm{mTOR}$ $\left.\mathrm{IC}_{50}=414 / 2790 \mathrm{nM}\right)$. Then aiming to interact with Lys 833 in the affinity pocket, the methoxypyridine was modified by introducing diverse substituents in the 3-position. Compound 148 (PI3K $\alpha / \mathrm{mTOR} \mathrm{IC}_{50}=2.82 / 45.8 \mathrm{nM}$ ) was discovered, which would be further optimized due to low permeability.

Consequently, Lin et al [63] from the same team reported the identification of novel 7-amino-5-methyl-1, 6-naphthyridin-2(1H)-one derivatives (149-156) as potent $\mathrm{PI} 3 \mathrm{~K} / \mathrm{mTOR}$ dual inhibitors, by exploring the 4-methylpyridopyrimidinone (MPP), which was proven to be a potent scaffold for PI3K/mTOR dual inhibitors, such as PF-04691502 (122, PI3K $\alpha / \mathrm{mTOR} \mathrm{Ki}=0.57 / 16 \mathrm{nM})$.
The identified representative compound (e.g. 157, PI3K $\alpha /$ mTOR $\mathrm{IC}_{50}=2.42 / 8.55 \mathrm{nM}$ ) demonstrated acceptable potency, cellular activity and pharmacokinetic profile.

To discovered novel PI3K $\alpha / \mathrm{mTOR}$ inhibitors, 2-amine-4- heterocyclic aryl-disubsituted pyrido[2,3-d]and pyrido[3,2-d] pyrimidines with (158-161)were designed by Saurat et al [64] . Seven promising PI3K $\alpha$ / mTOR dual inhibitors $\left(\mathrm{IC}_{50}\right.$ values $\left.<100 \mathrm{nM}\right)$ were discovered, and two urea derivatives $162(\mathrm{PI} 3 \mathrm{~K} \alpha / \mathrm{mTOR}$ $\left.\mathrm{IC}_{50}=58 / 5 \mathrm{nM}\right)$ and $163\left(\mathrm{PI} 3 \mathrm{~K} \alpha / \mathrm{mTOR} \mathrm{IC}_{50}=40 / 1 \mathrm{nM}\right)$ were further developed to enhance their efficacy.

Zhu et al [65] reported the discovery of 7, 8-dihydro-5H-thiopyrano [4, 3-d] pyrimidine derivatives (165-166) as mTOR inhibitors, using scaffold hopping of the lead compound (164, $\left.\mathrm{mTOR} \mathrm{IC}_{50}=1.37 \mu \mathrm{M}\right)$, a triazinehydrazone derivative. The selected compounds $\left(\mathrm{mTOR} \mathrm{IC}_{50} \sim 0.8-6.93 \mu \mathrm{M}\right)$ ) showing equal to more potency than the lead were further evaluated for the inhibitory activity against $\mathrm{PI} 3 \mathrm{~K} \alpha\left(\mathrm{PI} 3 \mathrm{~K} \alpha \mathrm{IC}_{50} \sim 6.2-\right.$ $24.9 \mu \mathrm{M})$. SARs and docking studies showed that "the thiopyrano [4, 3-d] pyrimidine scaffold had little effect on the antitumor activities, while variations in substitutions of the aryl moieties had a significant impact on the activities and 4-OH substitution produced the best potency".

Shao et al [66] designed 2-substituted-3sulfonamino- 5- (4-morpholinoquinazolin-6-yl) benzamides (167) as bioisostere of GSK2126458 (143). Compound 168 with potent antiproliferative activity in vitro was selected for PI3K /mTOR enzymatic activity assay $\left(\mathrm{PI} 3 \mathrm{~K} \alpha / \beta / \delta / \gamma \quad \mathrm{IC}_{50}=14 / 190 / 74 / 56 \mathrm{nM}, \quad \mathrm{mTOR}\right.$ $\mathrm{IC}_{50}=65 \mathrm{nM}$ ), Western blot assay and anticancer effects in vivo, and the result confirmed that these compounds could be potent PI3K inhibitors and anticancer agents. Furthermore, the docking result of 168 with $\mathrm{PI} 3 \mathrm{~K} \gamma$ indicated that benzamide group could replace the complex of pyridine with water molecule in GSK2126458.

To discover dual pan-PI3K/mTOR inhibitors, Poulsen et al [67] generated a pharmacophore model and designed a series of novel compounds based on a purine scaffold. Three scaffolds (A-C) having a purine core substituted with a morpholine, a phenol headgroup, and a hydrophobic substituent were initially designed from three reference compounds PI-103(102), LY294002 (3) and ZSTK474 (169). Scaffold (A) was chosen for synthetic reason. The extensive SAR study of the headgroup, 8-position and 9-position substituents(170-177), utilizing the docking difference between PI3K $\alpha$ and mTOR, resulted in potent inhibitors with good pharmacokinetic properties, of which, a dual mTOR/PI3K inhibitor SB2343(178, VS-5584) and a selective mTOR inhibitor SB2602 (179) progressed into clinical trial.

Dihydropyrrolopyrimidine derivative (180, $\mathrm{PI}_{3 \mathrm{~K} \alpha \mathrm{IC}_{50}}=42 \mathrm{nM}$ ) was identified as a metabolically stable and potent PI3K inhibitor initially, while with poor oral bioavailability. To remove the $\mathrm{H}$-bond acceptor and recover the water solubility, Kawada et al [68] designed 
pyridine, benzylamine and benzamide derivatives (181, $\mathrm{PI}_{3 \mathrm{~K} \alpha \mathrm{IC}_{50}} \sim 14-220 \mathrm{nM}$ ), by adding amine or amide (piperazine, morpholine) as a solubilizing group, replacing pyridine with a phenyl moiety and introducing an orthosubstituent in the phenyl group. Finally, compound 182 was identified with good pharmacokinetic profiles (oral bioavailability in monkey 8 times better than that of compound 180) and $\mathrm{PI} 3 \mathrm{Ka}$ inhibition (PI3K $\alpha \mathrm{IC}_{50}=42$ $\mathrm{nM})$.

In 2016, to improve the low solubility of compound (183, PI3K $\alpha=13 \mathrm{nM}$ ) by introducing a solubilizing group and ortho substituents to break molecular planarity, phenylurea derivative 184 (PI3K $\alpha \sim 10-260 \mathrm{nM}$ ) were designed by Kawada et al [69]. Finally, compound 185 (PI3K $\alpha / \beta=22 / 7 \mathrm{nM}$ ) with moderate solubility showed strong tumor growth inhibition in vivo.

Zhang et al [70] reported a series of N-(2-methoxy5-(3-substituted quinazolin-4(3H)-one-6-yl) -pyridin3-yl) phenyl sulfonamide (187-190) as PI3K inhibitors, using compound 186 as the lead. All compounds exhibited significant anti proliferative activities, of which, compounds $191\left(\mathrm{PI} \mathrm{K} \alpha / \beta / \delta / \gamma \mathrm{IC}_{50}=7.3 / 209 / 106 / 116\right.$ $\mathrm{nM}$, mTORIC $\left._{50}=208 \mathrm{nM}\right)$ and $192\left(\mathrm{PI} 3 \mathrm{~K} \alpha / \beta / \delta / \gamma \mathrm{IC}_{50}=\right.$ $6.7 / 24 / 21 / 181 \mathrm{nM}$, mTORI $_{50}=114 \mathrm{nM}$ ) displayed potent inhibitory activity against PI3K and mTOR.

\section{PYRIDINES, QUINOLINES, INDOLES AND INDAZOLES}

Mostly, the few PI3K inhibitors based on pyridine, quinoline and indole structures reported since 2010 have been identified to be selective against PI3K $\alpha$ or mTOR, including GSK2126458 (143), the most potent PI3K inhibitor with low picomolar activity.

In 2010, Barile et al [16] identified a novel scaffold of the 3-ethynyl-1H-indazoles (193), as multiple PI3K/ PDK1/mTOR inhibitors, and discovered a PI3K $\alpha$ isoformspecific compound (194), with 100-fold selectivity over the $\beta$ - and $\gamma$-isoforms $\left(\mathrm{IC}_{50}=0.36,40,10.7,39\right.$ and 3.87 $\mu \mathrm{M}$ for PI3K $\alpha, \mathrm{PI} 3 \mathrm{~K} \beta, \mathrm{PI} 3 \mathrm{~K} \delta, \mathrm{PI} 3 \mathrm{~K} \gamma, \mathrm{mTOR}$ and PDK, respectively). The binding mode revealed that "compound 194 was deeply inserted by forming hydrogen bonds with residues in the ATP-binding site: the N-2 with Tyr836 and Asp933, the NH-1 with Asp810, NH of the pyridine ring and Val851 of the hinge region".

Zhang et al [71] (Wyeth) developed a series of 5-ureidobenzofuran-3-one indoles (195-197), as potent inhibitors of PI3K $\alpha\left(\mathrm{IC}_{50} \sim 0.2-1 \mathrm{nM}\right)$ and $\mathrm{mTOR}\left(\mathrm{IC}_{50}\right.$ $\sim 0.3-1000 \mathrm{nM})$. The most potent compounds were 198 $\left(\mathrm{PI} 3 \mathrm{~K} \alpha / \mathrm{mTOR} \mathrm{IC}_{50}=0.3 / 1 \mathrm{nM}\right)$ and $199(\mathrm{PI} 3 \mathrm{~K} \alpha / \mathrm{mTOR}$ $\left.\mathrm{IC}_{50}=0.2 / 0.3 \mathrm{nM}\right)$, with a 4 -[2-(dimethylamino) ethyl] methylamino amidophenyl group and 7-fluoro substituted on the indole ring. The predicted binding mode indicated that "the larger group (R1, R2) was more favorable for binding to mTOR, without affecting interactions with PI3K $\alpha$ ".
Knight et al [72] (GlaxoSmithKline) reported the discovery of GSK2126458 (143), a highly potent, orally bioavailable PI3K/ mTOR inhibitor $(\mathrm{Ki}=$ 0.019/0.03/0.024/0.06/0.18/0.3 $\mathrm{nM}$ for $\mathrm{PI} 3 \mathrm{~K} \alpha / \beta / \delta / \gamma$, mTORC1 and mTORC2 respectively), as follow-up studies of GSK1059615 (200, PI3K $\alpha \mathrm{Ki}=2 \mathrm{nM})$, their first PI3K clinical compound. The crystal structure of 200 indicated that larger groups (e.g. pyridine, indazole, formazaindazole, pyridylsulfonamide, arylsulfonamides), instead of the thiazolidinedione (TZD) ring, could improve potency and selectivity. Then pyridine analogues (201) were designed and GSK2126458 (143) with low picomolar activity was identified. Cocrystal structure showed that the sulfonamide group made a strong charged interaction with Lys833, which may explain the superior potency of 143.

Hong et al [73] identified a series of [3, 5-d]-7azaindole analogs (202-203) as PI3K $\alpha$ inhibitors, by varying groups on the 3,5-positions of azaindole. In their pharmacophore- directed design, through fragmentbased approach, 7-azaindole possessing both H-donor and $\mathrm{H}$-acceptor was selected as a scaffold, and the pyridyl sulfonamide pharmacophore was introduced at C5position to interact with the back pocket (DFG-motif, gate keeper and catalytic lysine). These 7-azaindole derivatives exhibited modest to good activity in cellular proliferation (PI3K $\alpha \mathrm{IC} 50=3 \sim 5200 \mathrm{nM}$ ) and in apoptosis assays.

In 2011, Kim et al [74] designed and synthesized a new series of imidazo [1, 2-a] pyridine derivatives (204$205)$ as PI3K $\alpha$ inhibitors (PI3K $\left.\alpha \mathrm{IC}_{50} \sim 0.2-720 \mathrm{nM}\right)$. With the selected imidazopyridine as the hinge linker binder and pyridyl sulfonamide as the back pocket group, they explored the structures by attaching diverse groups at the $\mathrm{C} 3$ position to fill the ribose pocket. The SAR results showed that some moieties (e.g., ester, nitrile, oxadiazole, tetrazole, and pyridine) at the $\mathrm{C} 3$ position profoundly influenced PI3K $\alpha$ binding affinity (e.g. compound 206208, PI3K $\alpha \mathrm{IC}_{50} \sim 1 \mathrm{nM}$ ).

In 2011, Liu et al [75] discovered benzonaphthyridinone analogs (210) as potent and selective small molecule mTOR inhibitors, by replacing the metabolically labile 4-amino-phenylpiperazine moiety of mTOR inhibitor Torin1 (209, PI3K $\gamma / \mathrm{mTOR} \mathrm{EC}_{50}=$ $1800 / 2 \mathrm{nM}$ ) with a phenyl ring. Further modification resulted in a new mTOR inhibitor $(231, \mathrm{PI} 3 \mathrm{~K} \gamma / \mathrm{mTOR}$ $\mathrm{EC}_{50}=1000 / 5 \mathrm{nM}$ ) that had significantly improved stability, as well as retained potency and selectivity.

As their continued study, they [76] discovered Torin $2\left(213, \mathrm{PI} 3 \mathrm{~K} / \mathrm{mTOR} \mathrm{EC}_{50}=200 / 0.25 \mathrm{nM}\right)$ as a potent, selective, and orally available mTOR inhibitor, utilizing a focused medicinal chemistry approach guided by cellular assays and pharmacokinetic and pharmacodynamic assays of compounds 212. The co-crystal structure revealed that the aminopyridine group formed three hydrogen bonds in the hydrophobic pocket.

Nishimura et al [77] reported the discovery of a series of substituted quinolines and quinoxalines 
derivatives (215-217), as potent $\mathrm{PI} 3 \mathrm{~K} / \mathrm{mTOR}$ dual inhibitors (e.g. 203, PI3K $\alpha \mathrm{Ki}=0.6 \mathrm{nM}$ ) with excellent pharmacokinetic properties and in vivo efficacies, using compound (214) as the lead. Initially, analogues with 6, 6-bicyclic heterocycles (quinoline, isoquinoline, quinoxaline, quinazoline, cinnoline, and naphthyridine) were designed, to replace the benzothiazole, as hinge linker binder. Then by incorporating suitable substituents at the 4-position of the quinoline or the 3-position of the quinoxaline rings, excellent cellular potencies were achieved, which indicated that the ribose pocket of the enzyme can be effectively utilized in optimizing both the potency and the physicochemical properties of PI3K inhibitors [77].

In 2013, Li et al [78] synthesized HS-106 (219, $\mathrm{PI} 3 \mathrm{~K} \alpha \quad \mathrm{IC}_{50}=11 \mathrm{nM}$ ), by screening the above chemical library of imidazopyridine derivatives [74]. They found this compound "suppressed breast cancer cell proliferation and induced apoptosis by inducing apoptosis and suppressing angiogenesis", which could be a potential drug for breast cancer treatment.

In order to design and optimize 3-pyridine heterocyclic derivatives as PI3K/mTOR dual inhibitors, molecular docking and 3D-quantitative structure-activity relationship (3D-QSAR) studies based on the ligand alignment and receptor alignment were applied using the comparative molecular field analysis (CoMFA) and comparative molecular similarity indices analysis (CoMSIA) were carried out by Yang et al [79]. Highly accurate and predictive 3D-QSAR models for designing new PI3K/mTOR inhibitors were constructed (Skelton 220-222), which would be useful for predicting activity and guiding the ligand modification of PI $3 \mathrm{~K} / \mathrm{mTOR}$ inhibitors.

Tsou et al (Weyth) [80] discovered 2-(4-substituted-pyrrolo [2, 3-b] pyridin-3-yl) methylene4-hydroxybenzofuran-3(2H)-ones (224-231) as potent and selective mTOR inhibitors. With the indole bearing 4, 6-dihydroxy benzofuranone (223) as the lead, a variety of 4-substituents, including 4-hydroxy phenyl, 4-benzamides and 4-piperidine amides were introduced on the indole. Also, since phenolic $\mathrm{OH}$ group was metabolically liable, one of the two hydroxyl groups was selectively removed. These optimizations generated subnanomolar, selective mTOR kinase inhibitors (mTOR $\mathrm{IC}_{50}=0.39-180 \mathrm{nM}$, $\mathrm{PI} 3 \mathrm{~K} \alpha \mathrm{IC}_{50}=16-5895 \mathrm{nM}$ ) with low nanomolar cellular activity.

In 2015, Lv et al [81] synthesized novel 4-alkynylquinoline derivatives (232-234) as $\mathrm{PI} 3 \mathrm{~K} / \mathrm{mTOR}$ dual inhibitors (PI3K $\alpha \mathrm{IC}_{50} \sim 1.63-300 \mathrm{nM}$ ) by modification of GSK2126458 (143). "To improve the water solubility and explore potential interactions with residues in the ribose pocket (e.g. Lys802 and Ala805)", the pyridazine of GSK2126458 was replaced with a hydrophilic substituent, while an alkyne was employed as a linkage between this hydrophilic group and the quinolone core. The target compounds showed potent $\mathrm{PI} 3 \mathrm{~K} \alpha$ inhibitory activities (PI3K $\alpha$ IC $_{50} \sim 1.63-300 \mathrm{nM}$ ) and good anti-proliferative effects. Compound 235, the 4-hydroxylpiperidine derivative, was further identified as a potent PI3K/mTOR dual inhibitor $\left(\mathrm{PI} 3 \mathrm{~K} \alpha / \beta / \delta / \gamma \mathrm{IC}_{50}=1.63 / 6.91 / 2.14 / 0.38 \mathrm{nM}\right.$, $\left.\mathrm{mTORIC}_{50}=3.26 \mathrm{nM}\right)$.

\section{Pyrazines and quinoxalines}

Given that the pan PI3K inhibitors XL-765 (236) and XL-147 (237) in clinical trials was quinoxaline derivatives, few PI3K inhibitors based on pyrazine and quinoxaline core have been developed, while with limited potency mostly.

In 2011, Wu et al [82] synthesized a series of novel 2-arylamino-3-(arylsulfonyl)quinoxalines (238) through a newly developed approach from XL-765 (236, PI3K $\alpha / \beta$ / $\left.\delta / \gamma \mathrm{IC}_{50}=39 / 113 / 43 / 9 \mathrm{nM}\right)$ and XL-147 (237, PI3K $\alpha / \beta /$ $\left.\delta / \gamma \mathrm{IC}_{50}=39 / 383 / 36 / 23 \mathrm{nM}\right)$. The most potent compound (239, PI3K $\left.\alpha \mathrm{IC}_{50}=0.07 \mu \mathrm{M}\right)$ validated the potential of 2-arylamino- 3- (arylsulfonyl) quinoxaline series for cancer treatment by targeting PI3K $\alpha$.

$\mathrm{Wu}$ et al [83] identified novel piperidinylquinoxalines (242) and piperazinylquinoxalines (243-246) as PI3K $\alpha$ inhibitors, with previously identified morpholinoquinoxaline derivative $240\left(\mathrm{PI} 3 \mathrm{~K} \alpha \mathrm{IC}_{50}=0.44\right.$ $\mu \mathrm{M}$ ) and piperidinylquinoxaline derivative 241 (PI3K $\alpha$ $\left.\mathrm{IC}_{50}=0.025 \mu \mathrm{M}\right)$ as the lead. Modification at the 2-position of the quinoxaline scaffold and 4-substituent of phenylsulfonyl moiety led to novel PI3K $\alpha$ inhibitors with good to potent inhibitory activity (up to $24 \mathrm{nM}$ ).

In 2011, Mortensen et al [84] reported the discovery of the imidazo [4, 5-b] pyrazin-2-one series (247) as selective mTOR kinase inhibitors (e.g., 248 and 249). As the continued studies, through ring-expansion of the imidazo-ring by insertion of a methylene unit, they [85] discovered a new series of potent and selective mTOR kinase inhibitors (250) with exquisite kinase selectivity $\left(\mathrm{mTOR} \mathrm{IC}_{50} \sim 2-176 \mathrm{nM}, \mathrm{PI} 3 \mathrm{~K} \alpha \mathrm{IC}_{50}>=526 \mathrm{nM}\right)$, which led to the identification of CC214-2 (251, mTOR $\mathrm{IC}_{50}=0.002 \mathrm{nM}, \mathrm{PI} 3 \mathrm{~K} \alpha \mathrm{IC}_{50}=1.38 \mathrm{nM}$ ), an orally available mTOR kinase inhibitor with demonstrated anti-tumor activity in mice.

In 2012, Martinez et al [86] described a novel series of 8-morpholinyl-imidazo [1,2-a]pyrazines (252254 ) bearing an $\mathrm{N}$ atom in bridge head position as PI3K inhibitors, which showed good potency against PI3K $\delta$ and $\alpha$, with improved selectivity against mTOR kinase. The inhibitory activity of the most potent compound (255) was $2.8 \mathrm{nM}, 60 \mathrm{nM}$ and $>10 \mu \mathrm{M}$, against $\mathrm{PI} 3 \mathrm{~K} \delta, \alpha$ and $\mathrm{mTOR}$, respectively. Then a variety of PI3K inhibitors (256-258) were explored, by replacing the 4-indazol moiety with heteroaryls, C2 position with additional amino alkyl substituents and C3 position with simple substituents such as bromine and methyl [87]. Finally, ETP-46321(259) has identified as a potent and orally available PI3K $\alpha / \delta$ 
inhibitor $\left(\mathrm{PI} 3 \mathrm{~K} \alpha / \beta / \delta / \gamma \mathrm{IC}_{50}=2.3 / 170 / 14.3 / 17 \mathrm{nM}\right)$ with

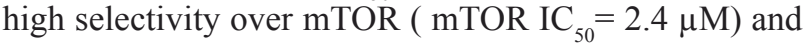
288 representative kinases.

\section{Azoles}

Azoles (including diazole, triazole, thiazole, oxadiazole, etc.), five-member heteroaryls of pyrimidine isosteres, are also the proper scaffolds for PI3K inhibitors. Compounds in this series always achieved isoform selectivity, e.g. PI3K $\beta$ selective inhibitor SAR260301 (332, PI3K $\left.\alpha / \beta / \delta / \gamma \mathrm{IC}_{50}=1539 / 23 / 469 / 10000 \mathrm{nM}\right), \mathrm{PI} 3 \mathrm{~K} \alpha$ selective inhibitor BYL719 (341, PI3K $\alpha / \beta / \delta / \gamma \quad \mathrm{IC}_{50}=$ $5 / 1200 / 290 / 250 \mathrm{nM})$ and GDC-0326 (310, PI3K $\alpha / \beta / \delta / \gamma$ $\left.\mathrm{IC}_{50}=0.2 / 26.6 / 4 / 10.2 \mathrm{nM}\right)$, as well as $\mathrm{PI} 3 \mathrm{~K} \alpha / \delta / \gamma$ inhibitor GDC-0032 (309, PI3K $\alpha / \beta / \delta / \gamma \quad$ IC $_{50}=0.29 / 9.1 / 0.12 / 0.97$ $\mathrm{nM}$ ).

In 2008, Alexander [88] identified 4-(1, 3-thiazol2-yl) morpholine derivatives (261) as potent and selective PI3K inhibitors by the modification of compound 260 $\left(\mathrm{PI} 3 \mathrm{~K} \alpha / \beta / \delta / \gamma \quad \mathrm{IC}_{50}=1333 / 693 / 701 / 3453 \mathrm{nM}\right)$. The most potent compounds lactam $263\left(\mathrm{PI} 3 \mathrm{~K} \alpha / \beta / \delta / \gamma \mathrm{IC}_{50}=\right.$ $59 / 1006 / 18 / 31 \mathrm{nM}$ ) showed similar potency to the ketone $262\left(\mathrm{PI} 3 \mathrm{~K} \alpha / \beta / \delta / \gamma \mathrm{IC}_{50}=51 / 1157 / 35 / 49 \mathrm{nM}\right)$, while 263 exhibited better in vivo pharmacokinetic profiling based on its superior solubility.

In 2011, Bengtsson et al [89] patented the 5-heteroaryl thiazole derivatives (264) or a pharmaceutically acceptable salt and their use as PI3K and/or mTOR inhibitors. In general, compounds of the invention possessed PI3K inhibitory activity with $\mathrm{PI} 3 \mathrm{~K} \gamma$ $\mathrm{IC}_{50} \sim 0.1-40 \mu \mathrm{M}$ and PI3K $\alpha \sim 0.1-4.5 \mu \mathrm{M}$.

Angelo et al [90] identified benzothiazole compound $265(\mathrm{PI} 3 \mathrm{~K} \alpha \mathrm{Ki}=53 \mathrm{nM}, \mathrm{mTOR} \mathrm{Ki}>25 \mu \mathrm{M})$ as an initial hit from HTS, and the crystal structure suggested that the ribose pocket might accommodate larger groups than pyrimidine. Extensive SAR studies, including the link atom (sulfur, oxygen and nitrogen) and the pyridine replacing pyrimidine (266-268), led to the sulfonamide $269(\mathrm{PI} 3 \mathrm{~K} \alpha \mathrm{Ki}=38 \mathrm{nM}$, mTOR $\mathrm{Ki}=269 \mathrm{nM})$ for as an early lead, with high in vitro and in vivo clearance. Subsequent modifications, including the central ring and the substitution (270-271), led to chloropyridine 272 (PI3K $\alpha \mathrm{Ki}<1 \mathrm{nM}$, mTOR Ki $=2.1 \mathrm{nM}$ ). Further phenyl sulfonamide SAR studies (273) optimizing in vitro clearance led to the identification of as a potent $\mathrm{PI} 3 \mathrm{~K} /$ mTOR dual inhibitor $274(\mathrm{PI} 3 \mathrm{~K} \alpha \mathrm{Ki}=1.2 \mathrm{nM}$, mTOR Ki $=$ $2.0 \mathrm{nM}$ ), with low clearance and high oral bioavailability.

Liu et al (Pfizer) [91] discovered tetra-substituted thiophenes as highly selective PI3K inhibitors, with compound $275(\mathrm{PI} 3 \mathrm{~K} \alpha \mathrm{Ki}=230 \mathrm{nM})$ as the lead, which was initially optimized by replacing the free carboxylic acid moiety with carboxylic amide $(276, \mathrm{PI} 3 \mathrm{~K} \alpha \mathrm{Ki}=13$ $\mathrm{nM}$ ). As nitrogen atom could form H-bond binding with a water molecule in the ATP binding site, different amide bioisosteres of compound 276 were designed (277-281), of which compound 277 with a 1, 2, 4-triazole group stand out $(\mathrm{PI} 3 \mathrm{~K} \alpha \mathrm{Ki}=1.7 \mathrm{nM}$, mTOR $\mathrm{Ki}=434 \mathrm{nM})$. $\mathrm{C}-4$ phenyl moiety was then replaced by diverse aryl and heteroaryl groups to maximize the mTOR selectivity. Finally, very potent compounds 282 (PI3K $\alpha \mathrm{Ki}=0.35 \mathrm{nM}$, mTOR Ki=2470 nM) and $283(\mathrm{PI} 3 \mathrm{Ka} \mathrm{Ki}=0.6 \mathrm{nM}$, mTOR $\mathrm{Ki}=1440 \mathrm{nM}$ ) with excellent selectivity over mTOR (up to 7000-fold) was discovered, which demonstrated good potency in vitro and in vivo, as well as the desired pharmacokinetic properties.

"Compound (284), a potent PI3K $\alpha / \mathrm{mTOR}$ inhibitor $\left(\mathrm{PI} 3 \mathrm{~K} \alpha \mathrm{IC}_{50}=1.2 \mathrm{nM}, \mathrm{mTOR} \mathrm{IC}_{50}=2.0 \mathrm{nM}\right)$ in vitro and in vivo, was found to undergo deacetylation on the 2-amino substituent to yield compound $285(\mathrm{PI} 3 \mathrm{~K} \alpha \mathrm{Ki}=$ $5.6 \mathrm{nM}, \mathrm{mTOR} \mathrm{IC}_{50}=84 \mathrm{nM}$ )". To reduce or eliminate this metabolic deacetylation, Stec et al [92] examined a variety of 6, 5-hetero-cyclic analogues (286) as an alternative to the benzothiazole ring. Finally, imidazopyridazine (287, PI3K $\alpha \mathrm{IC}_{50}=1.4 \mathrm{nM}$, mTOR $\mathrm{IC}_{50}=0.4 \mathrm{nM}$ ) was discovered, which exhibited similar in vitro potency and in vivo efficacy relative to the lead (284), while was more metabolically stable.

In 2012, Bruce (Novartis) et al [93] elaborated the progression from a pan-PI3K lead molecule (288, PI3K $\alpha / \delta / \gamma / \beta \mathrm{Ki}=0.11,0.11,0.21,1.43 \mu \mathrm{M})$ to $\alpha, \delta$ and $\gamma$ isoform selective Class I PI3K inhibitors (289-293), which was urea derivatives using parallel synthesis to combine amines (RR'NH) with selected aminothiazole scaffolds. These inhibitors with good isoform selectivity and cellular activity "would be pharmacological tools for elucidating the relative contributions of individual isoforms in PI3K signaling pathways".

Lin et al (GlaxoSmithKline) have reported [94, 95] the discovery of imidazopyrimidinone (294, $\mathrm{PI} 3 \mathrm{~K} \alpha / \beta / \gamma / \delta$ $\left.\mathrm{IC}_{50}=2.0 / 0.001 / 0.008 / 1 \mu \mathrm{M}\right)$ and triazolopyrimidinone (295, PI3K $\left.\alpha / \beta / \gamma / \delta \quad \mathrm{IC}_{50}=0.32 / 0.0003 / 0.004 / 0.06 \mu \mathrm{M}\right)$, as novel potent PI3K $\beta$ selective inhibitors, while with poor pharmacokinetic profile. Then they designed [96] thiazolopyrimidinones (296), with a substituted benzyl group at the N1-position to induce the selectivity-pocket formed by Met-779 and Trp-787, a morpholine as the hinge binder and a carbonyl group to interact with the back-pocket. These compounds demonstrated potency $\left(\mathrm{PI} 3 \mathrm{~K} \beta \mathrm{IC}_{50}=0.05-790 \mu \mathrm{M}\right)$ and good selectivity ( PI3K $\beta$ selectivity $>10$ fold), and compound 297 (PI3K $\alpha / \beta / \gamma / \delta$ $\left.\mathrm{IC}_{50}=2.5 / 0.0006 / 0.020 / 0.79 \mu \mathrm{M}\right)$ emerged as a potent, selective and orally bioavailable PI3K $\beta$ inhibitor.

Compound 298 was identified as an initial hit $\left(\mathrm{PI} 3 \mathrm{~K} \gamma \mathrm{IC}_{50}=5 \mathrm{nM}\right)$ through HTS by Oka et al [97] and the docking mode indicated that nitrogen atoms in the acetylaminothiazole formed hydrogen bonds to the hinge Val882, while the benzoic acid moiety interacted with Lys807 and Lys833. Thus, they optimized the central heterocycles as the replacement of thiazole and identified oxazole derivative $299\left(\mathrm{PI} 3 \mathrm{~K} \gamma \mathrm{IC}_{50}=12 \mathrm{nM}\right)$ as the lead for further optimization. A novel series of 2-aminothiazole- 
oxazole derivatives (300) were synthesized and evaluated as PI3K $\gamma$ inhibitors (PI3K $\gamma \mathrm{IC}_{50} \sim 3-346 \mathrm{nM}$ ), of which the trifluoroethyl and tert-butyl derivatives displayed good enzymatic and cellular activities.

Peterson et al [98] identified new imidazopyridine and imidazopyridazine scaffolds (303) that demonstrated superior mTOR inhibition and selectivity, starting from the previously reported triazine-benzimidazole (301, mTOR IC $\mathrm{IO}_{50}=23 \mathrm{nM}, \mathrm{PI} 3 \mathrm{~K} \alpha \mathrm{IC}_{50}=798 \mathrm{nM}$ ) and triazineimidazopyridine $\left(302, \mathrm{mTOR} \mathrm{IC}_{50}=12 \mathrm{nM}, \mathrm{PI} 3 \mathrm{~K} \alpha \mathrm{IC}_{50}=\right.$ $590 \mathrm{nM}$ ). To capping sites of glucuronidation(the pyrazole $\mathrm{NH}$ ) and indroducing a ribose substituent to improve pharmacokinetics and potency, the imidazopyridazine core and substitution of the linker-binder pyrimidine were explored, which resulted in potent and selective mTOR inhibitor (303, mTOR IC $\mathrm{IC}_{50} \sim 2-147 \mathrm{nM}, \mathrm{PI} 3 \mathrm{~K} \alpha \mathrm{IC}_{50} \sim 47-$ $12500 \mathrm{nM})$, with improved in vivo clearance.

In 2013, Morales et al [99] explored the 5-morpholino-7H thieno[3,2-b] pyran-7- ones (304) as potential PI3K inhibitors, with thiophene as the bioisostere of the phenyl ring of the classic pan-PI3K inhibitor LY294002. This series have improved potency with PI3K $\alpha$ selectivity (e.g., 305 , PI3K $\alpha / \beta / \gamma / \delta$ IC $50=$ $34 / 214 / 960 / 158 \mathrm{nM}$ ), while in some cases, displayed an unexpected PI3K $\delta$ selectivity (e.g. 306, PI3K $\alpha / \beta / \gamma / \delta$ IC $50=714 / 1750 / 27 / 1170 \mathrm{nM})$. The cell-based assay of these compounds also demonstrated potent cell growth inhibitory activity.

Then Ndubaku et al [100] (Genentech) derived a set of imidazobenzoxazepin compounds, by modification of compound 307, which displayed good in vitro potency (PI3K $\left.\alpha \mathrm{IC}_{50}<0.5 \mu \mathrm{M}\right)$, while had low solubility and high in vivo unbound clearance. These imidazobenzoxazepin derivatives (308, PI3K $\alpha \mathrm{IC}_{50} \sim 0.1-21.1 \mathrm{nM}$ ) had better tumor growth inhibition in vivo, and GDC-0032 (309, $\mathrm{PI} 3 \mathrm{~K} \alpha / \beta / \delta / \gamma \mathrm{IC}_{50}=0.29 / 9.1 / 0.12 / 0.97 \mathrm{nM}$ ) was identified, which was undergoing clinical development for use in PI3K-related cancers. Then in 2016, they reported [101] the discovery of a series of PI3K $\alpha$-specific inhibitors, which obtained PI $3 \mathrm{~K} \alpha$-selectivity through interactions with a non-conserved residue. Optimization of properties led to the identification of the clinical candidate GDC$0326\left(310, \mathrm{PI} 3 \mathrm{~K} \alpha / \beta / \delta / \gamma \mathrm{IC}_{50}=0.2 / 26.6 / 4 / 10.2 \mathrm{nM}\right)$.

Staben et al [102] (Genentech) had disclosed HTS derived thienobenzoxepin series (311) with aniline amide substituents as PI3K inhibitors, while the aniline amide was undesired and contributed to high clearance. To improve the clearance, stability and potency through interactions with the affinity pocket, they replaced he aniline amide with heterocyclic amide isosteres (312320). Overall, simple branched alkyl substituted triazoles had better properties than those halo aryl substituted derivatives. The replacement of 'cis'N-methyl aniline amides led to compound $321 \quad\left(\mathrm{PI} 3 \mathrm{~K} \alpha / \beta / \gamma / \delta \quad \mathrm{IC}_{50}=\right.$ 4.0/29/2.2/3.9 nM), a potent and selective PI3K inhibitor with high permeability, solubility and bioavailability.
To improve selectivity over $\mathrm{PI} 3 \mathrm{~K} \beta$ and decrease the high clearance due to the amide hydrolysis of compound 322(PI3K $\left.\alpha / \beta / \gamma / \delta \quad \mathrm{IC}_{50}=4.0 / 29 / 2.2 / 3.9 \mathrm{nM}\right)$, they [103] further optimized the 2-triazolyl-benzoxepin 8 -substitution, and replaced thiophene with other fivemembered-heteroaryls (323-328, PI3K $\alpha \mathrm{IC}_{50} \sim 0.04-1.9$ $n M, P I 3 K \beta$ selectivity 1.1-3160 fold). Finally, PI3K $\beta$ sparing inhibitor, compound 329 (PI3K $\beta \mathrm{Ki} / \mathrm{PI} 3 \mathrm{~K} \alpha \mathrm{Ki}$ $\sim 57$ fold, $\mathrm{PI} 3 \mathrm{~K} \alpha / \beta / \gamma / \delta \mathrm{Ki} \sim 0.27 / 15 / 0.55 / 0.61 \mathrm{nM}$ ) was discovered with a suitable pharmacokinetic profile. Furthermore, the binding mode revealed that "the selectivity might be due to difference in the conformation of a tryptophan residue present in all isoforms ( $\alpha$ TRP780, $\beta$ TRP781, $\delta$ TRP760, $\gamma$ TRP812)", which presented a new structure-based hypothesis for reducing inhibition of the PI3K $\beta$ isoform while maintaining activity against $\alpha, \delta$ and $\gamma$ isoforms.

The indoline amide (331), replacing the aniline of compound (330) with a secondary amine, displayed potent and selective PI3K $\beta$ inhibition $\left(\mathrm{IC}_{50}=460 \mathrm{nM}, 4 \mathrm{nM}, 28\right.$ $\mathrm{nM}$ and $>10 \mu \mathrm{M}$ for PI $3 \mathrm{~K} \alpha, \beta, \delta$ and $\gamma$, respectively), but had poor aqueous solubility due to a strong network of hydrogen bond and hydrophobic interactions. To improve the solubility, 2-methyl was introduced on the indoline to yield different substituted pyrimidone indoline amides (332, $\mathrm{IC}_{50} \sim 85-10000 \mathrm{nM}, 1-407 \mathrm{nM}, 2-4135 \mathrm{nM}, 1131-$ $10000 \mathrm{nM}$ for PI3K $\alpha, \beta, \delta$ and $\gamma$, respectively) by Certal et al [104] in 2014. Finally, compound 333 (SAR260301) was discovered as a potent and soluble PI3K $\beta$ inhibitor $\left(\mathrm{PI} 3 \mathrm{~K} \alpha / \beta / \delta / \gamma \quad \mathrm{IC}_{50}=1539 / 23 \mathrm{nM} / 469 / 10000 \mathrm{nM}\right)$, which entered clinical trial in patients with advanced cancer.

Meanwhile, a novel thiazole carboxamide series was designed (e.g., compound 335, $\mathrm{IC}_{50}=8280,45 \mathrm{nM}, 227$ $\mathrm{nM}$ and $>10,000 \mathrm{nM}$ on $\mathrm{PI} 3 \mathrm{~K} \alpha, \beta, \delta$ and $\gamma$, respectively) by a fragment based rescaffolding[104], starting from pyrimidone 334 (PI3K $\beta$ selective inhibitor, $\mathrm{IC}_{50}=10000$ $\mathrm{nM}, 42 \mathrm{nM}, 118 \mathrm{nM}$ and $>10000 \mathrm{nM}$ for PI3K $\alpha, \beta, \delta$ and $\gamma$, respectively). Then a series of morpholino thiazole derivatives were synthesized as PI3K $\beta$ selective inhibitors (336, $\mathrm{IC}_{50} \sim 395-10000 \mathrm{nM}, 8-340 \mathrm{nM}, 58-2723 \mathrm{nM}$ and $>4203 \mathrm{nM}$ for PI3K $\alpha, \beta, \delta$ and $\gamma$, respectively) with suitable properties.

Collier et al [105] discovered a series of C6 substituted benzothiazole and urea analogues (338339, PI3K $\gamma \mathrm{Ki} \sim 1-770 \mathrm{nM}$, PI3K $\alpha \mathrm{Ki} \sim 7-4000 \mathrm{nM})$ as $\mathrm{PI} 3 \mathrm{~K} \gamma$ selective inhibitors, evoluted from a reported phenylthiazole pan-PI3K inhibitor PKI-93 (337). From the X-ray crystallography of compound $340(\mathrm{PI} 3 \mathrm{~K} \gamma \mathrm{Ki}=$ $7 \mathrm{nM}, \mathrm{PI} 3 \mathrm{~K} \alpha \mathrm{Ki}=105 \mathrm{nM}$ ) bound to PI3K $\gamma$, they found that the propylimidazole group occupied a previously unreported hydrophobic cleft adjacent to the ATP binding site and residue differences (Gly829 and Ala885 in PI3K $\gamma$ ) in this region caused the PI3K isoforms selectivity.

Gerspacher et al [106] (Novartis) converted the 5-(pyridin-4-yl)thiazol-2-amino bicyclic core scaffold of BYL719 (341) into novel 4H-thiazolo[5', 4':4,5] 
pyrano[2,3-c]pyridine tricyclic scaffold ( 342), via an oxygen as the linker. Activity result showed that 343 $\left(\mathrm{PI} 3 \mathrm{~K} \alpha / \beta / \delta / \gamma \mathrm{IC}_{50}=5 / 670 / 220 / 200 \mathrm{nM}\right)$ exhibited similar or better biochemical potency, selectivity against PI3Ka and cellular activity, as well as favorable pharmacokinetic properties due to enhanced solubility, compared to noncyclized analogs BYL719 $\left(341, \mathrm{PI} 3 \mathrm{~K} \alpha / \beta / \delta / \gamma \mathrm{IC}_{50}=\right.$ 5/1200/290/250 nM).

\section{Triazines}

ZSTK474 (169), the first triazine derivatives as a potent pan class I PI3K inhibitor, was reported in 2006. With the liability of synthesis and suitable position of the substituent, PI3K inhibitors based on the triazine or triazine-benzimidazole core structure has been continued [107], such as PKI-587(348), PKI-179 (350).

In 2010, Richard et al [108] (Wyeth research) identified a variety of potent triazine mTOR inhibitors containing the (R)-3-methyl morpholine moiety and a pyridylureidophenyl group, which demonstrated good selectivity (greater than 500-fold) over the related PI3K $\alpha$ (344-346, mTOR IC I0 $_{50} \sim 0.2-3.6 \mathrm{nM}, \mathrm{PI} 3 \mathrm{~K} \alpha \mathrm{IC}_{50} \sim 41$ $1894 \mathrm{nM})$. SAR studies revealed that "the addition of basic amines at the 4-position of the ureidophenyl ring was welltolerated and offered the opportunity to develop inhibitors with improved physicochemical properties, while amide derivatives at the 4-position of the arylureidophenyl ring resulted in reduced selectivity over PI3K $\alpha$ but enhanced cellular activity".

Venkatesan et al [48] (Pfizer) discovered that a series of bis(morpholino-1,3,5-triazine) derivatives bearing bisaryl ureas (347) are potent dual PI3K/mTOR inhibitors. They also found that the amide bearing water solubilizing groups (eg, N (Me)2-piperidine,methylpiperazine, pyrrolidino-piperidine) enhanced potency, due to the increased $\mathrm{H}$-bond accepting ability. Finally, compound 348 $\left(\mathrm{PKI}-587, \mathrm{IC}_{50}=0.4,5.4,1.6 \mathrm{nM}\right.$ for PI3K $\alpha, \mathrm{PI} 3 \mathrm{~K} \gamma$ and $\mathrm{mTOR}$, respectively) was identified as a highly efficacious $\mathrm{PI} 3 \mathrm{~K} / \mathrm{mTOR}$ inhibitor in vitro and in vivo, which entered clinical trials as a single agent for i.v. administration.

However, PKI-587(348) could not be administrated orally because of poor permeability, low clog $\mathrm{P}$ and high molecular weight. Hence, to obtain an orally efficacious $\mathrm{PI} 3 \mathrm{~K} / \mathrm{mTOR}$ inhibitors by increasing the clog $\mathrm{P}$ and to lowering the molecular weight, a series of monomorpholino 1, 3, 5-triazine derivatives bearing a 3-oxa8-azabicyclo [3.2.1] octane were designed [109] (349, PI3K $\alpha \mathrm{IC}_{50} \sim 7-85 \mathrm{nM}, \mathrm{PI} 3 \mathrm{~K} \gamma \mathrm{IC}_{50} 44-717 \mathrm{nM}$, mTOR IC ${ }_{50}$ $\sim 0.32-93.5 \mathrm{nM})$. An orally efficacious dual PI3K/mTOR inhibitor, compound 350 (PKI-179, $\mathrm{IC}_{50}=8,74,0.42 \mathrm{nM}$ for PI3K $\alpha, \mathrm{PI} 3 \mathrm{~K} \gamma$ and $\mathrm{mTOR}$, respectively) with lower molecular weight was discovered. Moreover, the active metabolite of PKI-587 was determined to be 351 ( $\mathrm{IC}_{50}=$ 4, 33, 0.8nM for PI3K $\alpha, \mathrm{PI} 3 \mathrm{~K} \gamma$ and $\mathrm{mTOR}$, respectively).

In 2011, based on the triazolopyrimidine (55,
PKI-402) and triazine (348, PKI-587) scaffold as highly efficacious dual PI3K/mTOR inhibitors, Dehnhardt et al [110] (Pfizer) designed the novel 2-oxatriazines series (352-353), which also exhibited excellent potency and good metabolic stability. The most potent compound $354\left(\mathrm{PI} 3 \mathrm{~K} \alpha \mathrm{IC}_{50}=0.2 \mathrm{nM}\right.$, mTOR $\left.\mathrm{IC}_{50}=0.7 \mathrm{nM}\right)$ showed an in vitro profile comparable to PKI-587.

Peterson et al [111] discovered triazinebenzimidazoles as selective mTOR inhibitors, using compound $355\left(\mathrm{PI} 3 \mathrm{~K} \alpha \mathrm{IC}_{50}=0.32 \mu \mathrm{M}, \mathrm{mTOR} \mathrm{IC}_{50}=0.097\right.$ $\mu \mathrm{M}))$ as the lead. The synthesized triazines provided broader kinase selectivity and improved potency (356358 ), with diverse phenol bioisosteres to modify the affinity pocket binding moiety and the triazine linkerbinder replacement to improve the pharmacokinetic properties. Compound 359 (PI3K $\alpha \mathrm{IC}_{50}=2.2 \mu \mathrm{M}$, mTOR $\left.\mathrm{IC}_{50}=0.081 \mu \mathrm{M}\right)$ exhibited superior selectivity to other compounds, "with 200-fold selectivity over PI3Ka, and greater than 100-fold selectivity over the other PI3K isoforms".

As ZSTK474 (169, PI3K $\alpha / \beta / \delta / \gamma \mathrm{IC}_{50}=8.6 / 44 / 5 / 49$ $\mathrm{nM}$ ) had poor aqueous solubility which limited the development of an amorphous formulation [112], Rewcastle et al [113] explored the 2-substituted, 4-, 5- and 6-substituted and pyrimidine analogues of ZSTK474, to discover more soluble inhibitors (360-361). They found that substitution at the 4 and 6 positions of the benzimidazole ring generated highly potent PI3K inhibitors (e.g., compound 362, PI $3 \mathrm{~K} \alpha \mathrm{IC}_{50}=0.22 \mathrm{nM}$ ) with good pharmacokinetics and efficacy in vivo, while still had poor solubility properties.

In 2012, Smith et al [30] synthesized a series of highly selective class I PI3K inhibitors, starting from the potent $\mathrm{PI} 3 \mathrm{~K} / \mathrm{mTOR}$ dual inhibitor 363 $\left(\mathrm{PI} 3 \mathrm{~K} \alpha \mathrm{Ki}=350 \mathrm{nM}\right.$, mTOR $\left.\mathrm{IC}_{50}=93 \mathrm{nM}\right)$ with poor pharmacokinetic properties due to the glucuronidation of the phenolic substituents and extensive metabolism of the benzimidazole in vivo. As "pyridylpyrimidine and pyridylpurine scaffolds had been demonstrated to have good in vivo properties", scaffold 364 was explored, with additional substituents to interact with the ribose pocket (Ki values $<10 \mathrm{nM}$ against $\mathrm{PI} 3 \mathrm{~K} \alpha, \mathrm{PI} 3 \mathrm{~K} \beta, \mathrm{PI} 3 \mathrm{~K} \gamma$, $\mathrm{PI} 3 \mathrm{~K} \delta$ and $>1000$-fold selectivity against $\mathrm{mTOR})$. Finally, compound $365\left(\mathrm{PI} 3 \mathrm{~K} \alpha / \beta / \delta / \gamma \mathrm{Ki}=9 / 5 / 2 / 4 \mathrm{nM}\right.$, mTOR $\mathrm{IC}_{50}$ $=4800 \mathrm{nM}$ ) was discovered, with excellent selectivity over mTOR and related kinases.

In previous studies, Wurz et al [90] disclosed sulfonamide benzothiazole derivatives (e.g. 366, PI3K $\alpha \mathrm{Ki}$ $=1.2 \mathrm{nM}$, mTOR $\mathrm{IC}_{50}=2.1 \mathrm{nM}$ ) as potent PI3K/mTOR dual inhibitor, while had low solubility. Meanwhile, another series of PI3K inhibitors (e.g. 367, PI3K $\alpha \mathrm{Ki}=$

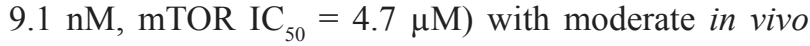
pharmacokinetic properties, was identified. Then structure 368 was designed by a hybrid strategy [113], which underwent modification to the sulfonamide of the affinity pocket binding motif (R1) and the ribose pocket binding 
motif (R2). A novel series of 4-amino-6-methyl- 1, 3, 5triazine sulfonamides were discovered as PI3K inhibitors (PI3K $\alpha \mathrm{Ki}$ 3.5-161 nM).

In 2013, Pinson et al [115] identified a series of amino acyl-triazine derivatives (369) as potent and isoform selective PI3K $\beta$ inhibitors, by modifying the pan-PI3K inhibitor ZSTK474. The selectivity based on the stereochemistry, with L-amino acyl derivatives preferring $\mathrm{PI} 3 \mathrm{~K} \beta$, while their D-congeners favored $\mathrm{PI} 3 \mathrm{~K} \delta$ (PI3K $\alpha \mathrm{IC}_{50} \sim 42-10000 \mathrm{nM}, \mathrm{PI} 3 \mathrm{~K} \beta \mathrm{IC}_{50} \sim 31-10000 \mathrm{nM}$, $\mathrm{PI} 3 \mathrm{~K} \delta \mathrm{IC}_{50} \sim 26-3600 \mathrm{nM}, \beta / \delta$ selectivity $\left.\sim 0.007-34\right)$. This could be explained by interaction with the non-conserved binding site residue ASP862 of PI3K $\beta$, which provided an alternate mechanistic basis for selectivity.

\section{Others}

To discover novel PI3K $\gamma$ inhibitors as anticancer agent, Taha et al [116] explored the pharmacophoric space of PI3K $\gamma$ via diverse inhibitors and used CATALYSTHYPOGEN to identify high quality binding model in 2014. Then QSAR model was assessed within training inhibitors (78 collected PI3K $\gamma$ inhibitors, scaffold 370378) and two associated models were validated by screening for new PI3K $\gamma$ ligands. 19 NCI hits (379-397) exhibited good to moderate potencies against PI3K $\gamma$ $\left(\mathrm{IC}_{50}=105-9157 \mathrm{nM}\right)$ in vitro, which suggested that "the combination of pharmacophoric exploration and QSAR analysis could be useful to find new and diverse PI3K $\gamma$ inhibitors".

\section{CONCLUSION}

Unregulated activation of the PI3K/Akt/mTOR pathway is a prominent feature of many human cancers and PI3K is activated or over-expressed in all major cancers. This makes PI3K as one of the most attractive anticancer targets, which may even circumvent drug resistance to current chemotherapies proved by preclinical and clinical evidences. The discovery of PI3K inhibitors brought a lot of promising compounds as drug candidates, a dozen of which have been advanced into preclinical or clinical trials for cancer treatment. Furthermore, the first approved PI3K inhibitor, Idelalisib (p110 $\delta$ selective) has already been used for the treatment of various hematological malignancies. However, there are many issues remained to be addressed.

Currently, the key point for the further development of PI3K inhibitors is selectivity. Much effort has been made to the development of class I PI3K inhibitors that exhibit sufficient isoform- selectivity and cross-kinase selectivity, with the help of the elucidation of the X-ray crystal structures of PI3K isoforms and those of their complexes with diverse inhibitors. As each PI3K isoform has its own function and is correspondingly involved in various diseases, it was assumed that the isoformspecific PI3K inhibitors may obtain lower toxicity, better tolerability and safety, while the pan- PI3K inhibitors could offer enhanced therapeutic efficacy. Likewisely, the $\mathrm{PI} 3 \mathrm{~K} / \mathrm{mTOR}$ dual inhibitors was considered to be more effective by delivering a powerful two-spot inhibition of the pathway and have the advantage of being less susceptible to PI3K drug resistance. "Will the isoformspecific inhibitors be more tolerable than pan-PI3K inhibitors", "Whether the dual inhibition of PI3K and mTOR is superior to inhibiting PI3K alone", "How to find the proper balance between the safety (only through kinase selectivity) and the therapeutic efficacy" are still questions remained to be addressed. And the answer will not be known until the completion of ongoing clinical trials.

\section{Abbreviations}

\author{
$\mathrm{PI} 3 \mathrm{~K}=$ phosphatidylinostitol-3-kinase \\ $\mathrm{Akt}=$ protein kinase $\mathrm{B}, \mathrm{PKB}$ \\ mTOR $=$ mammalian target of rapamycin \\ PTEN $=$ phosphatase and tensin homologue deleted \\ on chromosome ten \\ $\mathrm{RTK}=$ receptor tyrosine kinases \\ PIP2 = phosphatidylinositol 4, 5-bisphosphate \\ PIP3 = phosphatidylinositol 3, 4, 5-triphosphate \\ PDK1 = phosphatidyl inositol 3-dependent kinase 1 \\ mTORC $1=$ mTOR complex 1 \\ mTORC2 $=$ mTOR complex 2 \\ 4E-BP1 $=4 \mathrm{E}$-binding protein 1 \\ MDR1= multidrug resistance protein-1 \\ PIKKs $=$ PI3K-related kinases \\ DNA-PK= DNA- dependent protein kinase \\ GPCR $=$ G-protein-coupled receptors \\ $\mathrm{SAR}=$ Structure Activity Relationship \\ SBDD = Structure-based drug design \\ QSAR = Quantitative Structure-Activity \\ Relationship \\ HTS $=$ high throughput screening
}

\section{ACKNOWLEDGMENTS}

This work was supported by grants from Independent Innovation Foundation of Shandong University (No. 2012TS134), National Natural Science Foundation of China (No.81200344, 81470139).

\section{CONFICTS OF INTEREST}

The authors declare that there are no conflicts of interest.

\section{REFERENCES}

1. Wu P, Hu Y-Z. PI3K/Akt/mTOR Pathway Inhibitors in 
Cancer: A Perspective on Clinical Progress. Curr Med Chem. 2010; 17: 4326-41.

2. Lindsleya CW, Barnettb SF, Layton ME, MT B. The PI3K AThe PI3K/Akt Pathway: Recent Progress in the Development of ATP-Competitive and Allosteric Akt Kinase Inhibitors. Curr Cancer Drug Tar. 2008; 8: 7-18.

3. Hassan B, Akcakanat A, Holder AM, Meric-Bernstam F. Targeting the PI3-kinase/Akt/mTOR signaling pathway. Surg Oncol Clin N Am. 2013; 22: 641-664.

4. Sauveur-Michel Maira PFFS. Discovery of novel anticancer therapeutics targeting the PI3K/Akt/mTOR pathway. Future Med Chem. 2009; 1: 137-55.

5. Carnero A, Blanco-Aparicio C, Renner O, Link W, Leal JFM. The PTEN/PI3K/AKT signalling pathway in cancer therapeutic implications. Current Cancer Drug Targets. 2008; 8: 187-198.

6. Shaw RJ.; Cantley LC. Ras, PI(3)K and mTOR signalling controls tumour cell growth. Nature. 2006; 441: 424-430.

7. Lindsleya CW, Barnettb, S F, Yaroschak M, Bilodeau MT, Layton ME. Recent Progress in the Development of ATPCompetitive and Allosteric Akt Kinase Inhibitors. Curr Top Med Chem. 2007; 7: 1349-63.

8. Liu Y, Zhang DT, Liu XG. mTOR signaling in T cell immunity and autoimmunity. Int Rev Immunol. 2015; 34: 50-66.

9. Burris HA. Overcoming acquired resistance to anticancer therapy: focus on the PI3K/AKT/mTOR pathway. Cancer Chemother Pharmacol. 2013; 71: 829-42.

10. Chen Z, Venkatesan AM, Dehnhardt CM, Ayral-Kaloustian S, Brooijmans N, Mallon R, Feldberg L, Hollander I, Lucas J, Yu K, Kong F, Mansour TS. Synthesis and SAR of novel 4-morpholinopyrrolopyrimidine derivatives as potent phosphatidylinositol 3-kinase inhibitors. J Med Chem. 2010; 53: 3169-82.

11. Rodon J, Dienstmann R, Serra V, Tabernero J. Development of PI3K inhibitors: lessons learned from early clinical trials. Nat Rev Clin Oncol. 2013; 10: 143-153.

12. Kong D, Yamori T. Advances in Development of Phosphatidylinositol 3-Kinase Inhibitors. Curr Med Chem. 2009; 16: 2839-54.Chiarini F, Evangelisti C, McCubrey JA, Martelli AM. Current treatment strategies for inhibiting mTOR in cancer. Trends Pharmacol Sci. 2015; 36: 124-35.

13. Brachmann S, Fritsch C, Maira SM, Garcia-Echeverria C. PI3K and mTOR inhibitors: a new generation of targeted anticancer agents. Curr Opin Cell Biol. 2009; 21: 194-8.

14. Gonzalez-Angulo AM, Blumenschein GR, Jr. Defining biomarkers to predict sensitivity to PI3K/Akt/mTOR pathway inhibitors in breast cancer. Cancer Treat Rev. 2013; 39: 313-20.

15. Courtney KD; Corcoran RB; Engelman JA. The PI3K pathway as drug target in human cancer. J Clin Oncol. 2010; 28: 1075-1083.

16. Barile E, De SK, Carlson CB, Chen V, Knutzen C, RielMehan M, Yang L, Dahl R, Chiang G, Pellecchia M.
Design, synthesis, and structure-activity relationships of 3-ethynyl-1H-indazoles as inhibitors of the phosphatidylinositol 3-kinase signaling pathway. J Med Chem. 2010; 53: 8368-75.

17. Engelman, JA. Targeting PI3K signalling in cancer: opportunities, challenges and limitations. Nat Rev Cancer. 2009; 9: 550-562

18. Liu P, Cheng H, Roberts TM, Zhao JJ. Targeting the phosphoinositide 3-kinase pathway in cancer. Nat Rev Drug Discov. 2009; 8:627-644

19. Chen YL, Law PY, Loh HH. Inhibition of PI3K/Akt signaling: an emerging paradigm for targeted cancer therapy. Curr Med Chem Anticancer Agents. 2005, 5(6): 575-589.

20. Papadimitrakopoulou V. Development of PI3K/AKT/ mTOR Pathway Inhibitors and Their Application in Personalized Therapy for Non-Small-Cell Lung Cancer. J Thorac Oncol. 2012; 7: 1315-26.

21. Walker EH, Perisic OP, Ried C, Stephens L, Williams RL. Structure insight into pi3k catalysisi and signalling. Nature. 1999; 402: 313.

22. Ameriks MK, Venable JD. Small Molecule Inhibitors of Phosphoinositide 3-Kinase (PI3K)delta and gamma. Curr Top Med Chem. 2009; 9: 738-53.

23. Maira SM, Voliva C, Garcia-Echeverria C.Class IA phosphatidylinositol 3-kinase: from their biologic implication in human cancers to drug discovery. Expert Opin Ther Targets. 2008; 12(2): 223-238 .

24. Samuels Y, Wang Z, Bardelli A, Silliman N, Ptak J, Szabo S, Yan H, Gazdar A, Powell SM, Riggins GJ, Willson JK, Markowitz S, Kinzler KW, Vogelstein B, Velculescu VE. High frequency of mutations of the PIK3CA gene in human cancers. Science. 2004; 30: 554

25. Parsons DW, Wang TL, Samuels Y, Bardelli A, Cummins JM, DeLong L, Silliman N, Ptak J, Szabo S, Willson JK, Markowitz S, Kinzler KW, Vogelstein B, Lengauer C, Velculescu VE. Colorectal cancer: mutations in a signalling pathway. Nature. 2005; 436: 792.

26. Slomovitz BM, Coleman RL. The PI3K/AKT/mTOR pathway as a therapeutic target in endometrial cancer. Clin Cancer Res. 2012; 18: 5856-64.

27. Caino MC, Ghosh JC, Chae YC, Rivadeneira DB, Vaira V, Faversani A, Rampini P, Kossenkov AV, Aird KM, Zhang R, Webster MR, Weeraratna AT, Bosari S, Languino LR, Altieri DC. PI3K therapy reprograms mitochondrial trafficking to fuel tumor cell invasion. PNAS. 2015;112 (28) : 8638-8643.

28. Knight ZA, Gonzalez B, Feldman ME, Zunder ER, Goldenberg DD, Williams O, Loewith R, Stokoe D, Balla A, Toth B, Balla T, Weiss WA, Williams RL, et al. A pharmacological map of the PI3-K family defines a role for p110alpha in insulin signaling. Cell. 2006; 125: 733-47.

29. Walker EH. Structural Determinants of Phosphoinositide 3-Kinase Inhibition by Wortmannin, LY294002, Quercetin, 
Myricetin, and Staurosporine. Molecular Cell. 2000; 6: 90919.

30. Smith AL, D'Angelo ND, Bo YY, Booker SK, Cee VJ, Herberich B, Hong FT, Jackson CL, Lanman BA, Liu L, Nishimura N, Pettus LH, Reed AB, et al. Structure-based design of a novel series of potent, selective inhibitors of the class I phosphatidylinositol 3-kinases. J Med Chem. 2012; 55: 5188-219.

31. Dehnhardt CM, Venkatesan AM, Delos Santos E, Chen Z, Santos O, Ayral-Kaloustian S, Brooijmans N, Mallon R, Hollander I, Feldberg L, Lucas J, Chaudhary $\mathrm{I}, \mathrm{Yu} \mathrm{K}$, et al. Lead optimization of N-3-substituted 7-morpholinotriazolopyrimidines as dual phosphoinositide 3-kinase/mammalian target of rapamycin inhibitors: discovery of PKI-402. J Med Chem. 2010; 53: 798-810.

32. Vlahos C J, Matter WF, Hui KY, Brown RF. A Specific Inhibitor of Phosphatidylinositol 3-Kinase, 2-(4-Morpholinyl) -8-phenyl- 4H-1-benzopyran-4-one (3). J Biol Chem. 1994;269: 5241-5248.

33. Yuan TL, Cantley LC. PI3K pathway alterations in cancer: variations on a theme. Oncogene. 2008; 27: 5497-510.

34. Van Aller GS, Carson JD, Tang W, Peng H, Zhao L, Copeland RA, Tummino PJ, Luo L. Epigallocatechin gallate (EGCG), a major component of green tea, is a dual phosphoinositide-3-kinase/mTOR inhibitor. Biochem Biophys Res Commun. 2011; 406: 194-9.

35. Huang $\mathrm{S}$. Inhibition of PI3K/Akt/mTOR Signaling by Natural Products. Anticancer Agents Med Chem. 2013; 13: 967-70.

36. Folkes AJ, Ahmadi K, Alderton WK, Alix S, Baker SJ, Box Gary, Chuckowree IS, Clarke PA, Depledge P, Eccles SA, Friedman LS, Hayes A, Hancox TC, et al. The Identification of 2-(1H-Indazol-4-yl)-6-(4-methanesulfonyl- piperazin1-ylmethyl)-4- morpholin-4-yl-thieno[3,2-d]pyrimidine (GDC-0941) as a Potent, Selective, Orally bioavailable Inhibitor of Class I PI3 Kinase for the Treatment of Cance . J Med Chem. 2008; 51: 5522-5532.

37. Zask A, Verheijen JC, Curran K, Kaplan J, Richard DJ, Nowak P, Malwitz DJ, Brooijmans N, Bard J, Svenson K, Lucas J, Toral-Barza L, Zhang WG, et al. ATP-competitive inhibitors of the mammalian target of rapamycin: design and synthesis of highly potent and selective pyrazolopyrimidines. J Med Chem. 2009; 52: 5013-6.

38. Zask A, Kaplan J, Verheijen JC, Richard DJ, Curran K, Brooijmans N, Bennett EM, Toral-Barza L, Hollander I, Ayral-Kaloustian S, Yu K. Morpholine derivatives greatly enhance the selectivity of mammalian target of rapamycin (mTOR) inhibitors. J Med Chem. 2009; 52: 7942-5.

39. Verheijen JC, Richard DJ, Curran K, Kaplan J, Lefever M, Nowak P, Malwitz DJ, Brooijmans N, Toral-Barza L, Zhang WG, Lucas J, Hollander I, Ayral-Kaloustian S, et al. Discovery of 4-morpholino-6-aryl-1H-pyrazolo[3,4-d] pyrimidines as highly potent and selective ATP-competitive inhibitors of the mammalian target of rapamycin (mTOR): optimization of the 6-aryl substituent. J Med Chem. 2009;
52: 8010-24.

40. Liu KK, Bagrodia S, Bailey S, Cheng H, Chen H, Gao L, Greasley S, Hoffman JE, Hu Q, Johnson TO, Knighton D, Liu Z, Marx MA, et al. 4-methylpteridinones as orally active and selective PI3K/mTOR dual inhibitors. Bioorg Med Chem Lett. 2010; 20: 6096-9.

41. Nowak P, Cole DC, Brooijmans N, Bursavich MG, Curran KJ, Ellingboe JW, Gibbons JJ, Hollander I, Hu Y, Kaplan J, Malwitz DJ, Toral-Barza L, Verheijen JC, et al. Discovery of potent and selective inhibitors of the mammalian target of rapamycin (mTOR) kinase. J Med Chem. 2009; 52: 7081-9.

42. Malagu K, Duggan H, Menear K, Hummersone M, Gomez S, Bailey C, Edwards P, Drzewiecki J, Leroux F, Quesada MJ, Hermann G, Maine S, Molyneaux CA, et al. The discovery and optimisation of pyrido[2,3-d]pyrimidine-2,4diamines as potent and selective inhibitors of mTOR kinase. Bioorg Med Chem Lett. 2009; 19: 5950-3.

43. Pecchi S, Renhowe PA, Taylor C, Kaufman S, Merritt H, Wiesmann M, Shoemaker KR, Knapp MS, Ornelas E, Hendrickson TF, Fantl W, Voliva CF. Identification and structure-activity relationship of 2-morpholino 6-(3-hydroxyphenyl) pyrimidines, a class of potent and selective pi3 kinase inhibitors. Bioorganic \& medicinal chemistry letters. 2010;20:6895-6898

44. Heffron TP, Berry M, Castanedo G, Chang C, Chuckowree I, Dotson J, Folkes A, Gunzner J, Lesnick JD, Lewis C, Mathieu S, Nonomiya J, Olivero A, et al. Identification of GNE-477, a potent and efficacious dual PI3K/mTOR inhibitor. Bioorg Med Chem Lett. 2010; 20: 2408-11.

45. Verheijen JC, Yu K, Toral-Barza L, Hollander I, Zask A. Discovery of 2-arylthieno[3,2-d]pyrimidines containing 8-oxa-3-azabi-cyclo[3.2.1] octane in the 4-position as potent inhibitors of mTOR with selectivity over PI3K. Bioorg Med Chem Lett. 2010; 20: 375-9.

46. Verheijen JC, Richard DJ, Curran K, Kaplan J, Yu K, Zask A. 2-Arylureidophenyl-4-(3-oxa-8-azabicyclo[3.2.1] octan-8-yl) triazines as highly potent and selective ATP competitive mTOR inhibitors: optimization of human microsomal stability. Bioorg Med Chem Lett. 2010; 20: 2648-53.

47. Sutherlin DP, Sampath D, Berry M, Castanedo G, Chang Z, Chuckowree I, Dotson J, Folkes A, Friedman L, Goldsmith R, Heffron T, Lee L, Lesnick J, et al. Discovery of (thienopyrimidin-2-yl)aminopyrimidines as potent, selective, and orally available pan-PI3-kinase and dual panPI3-kinase/mTOR inhibitors for the treatment of cancer. J Med Chem. 2010; 53: 1086-97.

48. Venkatesan AM, Dehnhardt CM, Delos Santos E, Chen Z, Dos Santos O, Ayral-Kaloustian S, Khafizova G, Brooijmans N, Mallon R, Hollander I, Feldberg L, Lucas J, Yu K, et al. Bis(morpholino-1,3,5-triazine) derivatives: potent adenosine 5'-triphosphate competitive phosphatidylinositol-3-kinase/mammalian target of rapamycin inhibitors: discovery of compound 26 (PKI-587), 
a highly efficacious dual inhibitor. J Med Chem. 2010; 53: 2636-45.

49. Burger MT, Knapp M, Wagman A, Ni ZJ, Hendrickson T, Atallah G, Zhang Y, Frazier K, Verhagen J, Pfister K, Ng $\mathrm{S}$, Smith A, Bartulis S, et al. Synthesis and in Vitro and in Vivo Evaluation of Phosphoinositide-3-kinase Inhibitors. ACS Med Chem Lett. 2011; 2: 34-8.

50. Burger MT, Pecchi S, Wagman A, Ni ZJ, Knapp M, Hendrickson T, Atallah G, Pfister K, Zhang Y, Bartulis $\mathrm{S}$, Frazier K, Ng S, Smith A, et al. Identification of NVPBKM120 as a Potent, selective, Orally Bioavailable Class I PI3 Kinase Inhibitor for Treating Cancer. ACS Med Chem Lett. 2011; 2: 774-9.

51. Liu KK, Huang X, Bagrodia S, Chen JH, Greasley S, Cheng H, Sun S, Knighton D, Rodgers C, Rafidi K, Zou A, Xiao J, Yan S. Quinazolines with intra-molecular hydrogen bonding scaffold (iMHBS) as PI3K/mTOR dual inhibitors. Bioorg Med Chem Lett. 2011; 21: 1270-4.

52. Heffron TP, Wei B, Olivero A, Staben ST, Tsui V, Do $\mathrm{S}$, Dotson J, Folkes AJ, Goldsmith P, Goldsmith R, Gunzner J, Lesnick J, Lewis C, et al. Rational design of phosphoinositide 3-kinase alpha inhibitors that exhibit selectivity over the phosphoinositide 3-kinase beta isoform. J Med Chem. 2011; 54: 7815-33.

53. Wu X, Wang L, Han Y, Regan N, Li PK, Villalona MA, $\mathrm{Hu} \mathrm{X}$, Briesewitz R, Pei D. Creating diverse targetbinding surfaces on FKBP12: synthesis and evaluation of a rapamycin analogue library. ACS Comb Sci. 2011; 13: 486-95.

54. Sutherlin DP, Bao L, Berry M, Castanedo G, Chuckowree I, Dotson J, Folks A, Friedman L, Goldsmith R, Gunzner J, Heffron T, Lesnick J, Lewis C, et al. Discovery of a potent, selective, and orally available class I phosphatidylinositol 3-kinase (PI3K)/mammalian target of rapamycin (mTOR) kinase inhibitor (GDC-0980) for the treatment of cancer. J Med Chem. 2011; 54: 7579-87..

55. Finlay MR, Buttar D, Critchlow SE, Dishington AP, Fillery SM, Fisher E, Glossop SC, Graham MA, Johnson T, Lamont GM, Mutton S, Perkins P, Pike KG, et al. Sulfonylmorpholino-pyrimidines: SAR and development of a novel class of selective mTOR kinase inhibitor. Bioorg Med Chem Lett. 2012; 22: 4163-8.

56. Koehler MF, Bergeron P, Blackwood E, Bowman KK, Chen YH, Deshmukh G, Ding X, Epler J, Lau K, Lee L, Liu L, Ly $\mathrm{C}$, Malek S, et al. Potent, selective, and orally bioavailable inhibitors of the mammalian target of rapamycin kinase domain exhibiting single agent antiproliferative activity. J Med Chem. 2012; 55: 10958-71.

57. Le PT, Cheng H, Ninkovic S, Plewe M, Huang X, Wang H, Bagrodia S, Sun S, Knighton DR, LaFleur Rogers CM, Pannifer A, Greasley S, Dalvie D, et al. Design and synthesis of a novel pyrrolidinyl pyrido pyrimidinone derivative as a potent inhibitor of PI3Kalpha and mTOR. Bioorg Med Chem Lett. 2012; 22: 5098-103.

58. Cheng H, Hoffman JE, Le PT, Pairish M, Kania R, Farrell
W, Bagrodia S, Yuan J, Sun S, Zhang E, Xiang C, Dalvie D, Rahavendran SV. Structure-based design, SAR analysis and antitumor activity of PI3K/mTOR dual inhibitors from 4-methylpyridopyrimidinone series. Bioorg Med Chem Lett. 2013; 23: 2787-92.

59. Cheng H, Li C, Bailey S, Baxi SM, Goulet L, Guo L, Hoffman J, Jiang Y, Johnson TO, Johnson TW, Knighton DR, Li J, Liu KK, et al. Discovery of the Highly Potent PI3K/mTOR Dual Inhibitor PF-04979064 through Structure-Based Drug Design. ACS Med Chem Lett. 2013; 4: 91-7.

60. Leahy JW, Buhr CA, Johnson HW, Kim BG, Baik T, Cannoy J, Forsyth TP, Jeong JW, Lee MS, Ma S, Noson $\mathrm{K}$, Wang L, Williams M, et al. Discovery of a novel series of potent and orally bioavailable phosphoinositide 3-kinase gamma inhibitors. J Med Chem. 2012; 55: 5467-82.

61. Lee W, Ortwine DF, Bergeron P, Lau K, Lin L, Malek S, Nonomiya J, Pei Z, Robarge KD, Schmidt S, Sideris S, Lyssikatos JP. A hit to lead discovery of novel N-methylated imidazolo-, pyrrolo-, and pyrazolo-pyrimidines as potent and selective mTOR inhibitors. Bioorg Med Chem Lett. 2013; 23: 5097-104.

62. Han F, Lin S, Liu P, Tao J, Yi C, Xu H. Synthesis and structure-activity relationships of $\mathrm{PI} 3 \mathrm{~K} / \mathrm{mTOR}$ dual inhibitors from a series of 2-amino-4-methylpyrido[2,3-d] pyrimidine derivatives. Bioorg Med Chem Lett. 2014; 24 : 4538-41.

63. Lin S, Han F, Liu P, Tao J, Zhong X, Liu X, Yi C, Xu H. Identification of novel 7-amino-5-methyl-1,6-naphthyridin$2(1 \mathrm{H})$-one derivatives as potent $\mathrm{PI} 3 \mathrm{~K} / \mathrm{mTOR}$ dual inhibitors. Bioorg Med Chem Lett. 2014; 24: 790-3.

64. Saurat T, Buron F, Rodrigues N, de Tauzia ML, Colliandre L, Bourg S, Bonnet P, Guillaumet G, Akssira M, Corlu A, Guillouzo C, Berthier P, Rio P, et al. Design, synthesis, and biological activity of pyridopyrimidine scaffolds as novel PI3K/mTOR dual inhibitors. J Med Chem. 2014; 57: 61331.

65. Zhu W, Sun C, Xu S, Wu C, Wu J, Xu M, Zhao H, Chen L, Zeng W, Zheng P. Design, synthesis, anticancer activity and docking studies of novel 4-morpholino-7,8-dihydro$5 \mathrm{H}$-thiopyrano[4,3-d]pyrimidine derivatives as mTOR inhibitors. Bioorg Med Chem. 2014; 22: 6746-54.

66. Shao T, Wang J, Chen JG, Wang XM, Li H, Li YP, Li Y, Yang GD, Mei QB, Zhang SQ. Discovery of 2-methoxy3-phenylsulfonamino-5-(quinazolin-6-yl or quinolin-6-yl) benzamides as novel PI3K inhibitors and anticancer agents by bioisostere. Eur J Med Chem. 2014; 75: 96-105.

67. Poulsen A, Nagaraj H, Lee A, Blanchard S, Soh CK, Chen D, Wang H, Hart S, Goh KC, Dymock B, Williams M. Structure and ligand-based design of mTOR and PI3kinase inhibitors leading to the clinical candidates VS-5584 (SB2343) and SB2602. J Chem Inf Model. 2014; 54: 323850.

68. Kawada H, Ebiike H, Tsukazaki M, Yamamoto S, Koyama K, Nakamura M, Morikami K, Yoshinari K, Yoshida M, 
Ogawa K, Shinma N, Tsukuda T, Ohwada J. Modification of a dihydropyrrolopyrimidine phosphoinositide 3-kinase (PI3K) inhibitor to improve oral bioavailability. Bioorg Med Chem. 2015; 23: 7650-60.

69. Kawada H, Ebiike H, Tsukazaki M, Yamamoto S, Koyama K, Nakamura M, Morikami K, Yoshinari K, Yoshida M, Ogawa K, Shimma N, Tsukuda T, Ohwada J. Optimization of the phenylurea moiety in a phosphoinositide 3-kinase (PI3K) inhibitor to improve water solubility and the PK profile by introducing a solubilizing group and ortho substituents. Bioorg Med Chem. 2016; 24: 2897-906.

70. Zhang H, Xin MH, Xie XX, Mao S, Zuo SJ, Lu SM, Zhang SQ. Synthesis and antitumor activity evaluation of PI3K inhibitors containing 3-substituted quinazolin-4(3H)-one moiety. Bioorg Med Chem. 2015; 23: 7765-76.

71. Zhang N, Ayral-Kaloustian S, Anderson JT, Nguyen T, Das S, Venkatesan AM, Brooijmans N, Lucas J, Yu K, Hollander I, Mallon R. 5-ureidobenzofuranone indoles as potent and efficacious inhibitors of PI3 kinase-alpha and mTOR for the treatment of breast cancer. Bioorg Med Chem Lett. 2010; 20: 3526-9.

72. Knight SD, Adams ND, Burgess JL, Chaudhari AM, Darcy MG, Donatelli CA, Luengo JI, Newlander KA, Parrish CA, Ridgers LH, Sarpong MA, Schmidt SJ, Van Aller GS, et al. Discovery of GSK2126458, a Highly Potent Inhibitor of PI3K and the Mammalian Target of Rapamycin. ACS Med Chem Lett. 2010; 1: 39-43.

73. Donghee Kim HJ, Hyunseung Lee, Soon-Sun Hong, Sungwoo Hong. Development of New Fluorescent Xanthines as Kinase Inhibitors. ORGANIC LETTERS. 2010; 12: 1212-5.

74. Kim O, Jeong Y, Lee H, Hong SS, Hong S. Design and synthesis of imidazopyridine analogues as inhibitors of phosphoinositide 3-kinase signaling and angiogenesis. J Med Chem. 2011; 54: 2455-66.

75. Liu Q, Wang J, Kang SA, Thoreen CC, Hur W, Choi HG, Waller DL, Sim T, Sabatini DM, Gray NS. Discovery and optimization of potent and selective benzonaphthyridinone analogs as small molecule mTOR inhibitors with improved mouse microsome stability. Bioorg Med Chem Lett. 2011; 21: 4036-40.

76. Liu Q, Wang J, Kang SA, Thoreen CC, Hur W, Ahmed T, Sabatini DM, Gray NS. Discovery of 9-(6-aminopyridin3-yl)-1-(3- (trifluoromethyl) phenyl)benzo [h][1,6] naphthyridin-2( $1 \mathrm{H})$-one (Torin2) as a potent, selective, and orally available mammalian target of rapamycin (mTOR) inhibitor for treatment of cancer. J Med Chem. 2011; 54: 1473-80.

77. Nishimura N, Siegmund A, Liu L, Yang K, Bryan MC, Andrews KL, Bo Y, Booker SK, Caenepeel S, Freeman D, Liao H, McCarter J, Mullady EL, et al. Phospshoinositide 3-kinase $(\mathrm{PI} 3 \mathrm{~K}) /$ mammalian target of rapamycin (mTOR) dual inhibitors: discovery and structure-activity relationships of a series of quinoline and quinoxaline derivatives. J Med Chem. 2011; 54: 4735-51.
78. Li GY, Jung KH, Lee H, Son MK, Seo J, Hong SW, Jeong Y, Hong S, Hong SS. A novel imidazopyridine derivative, HS-106, induces apoptosis of breast cancer cells and represses angiogenesis by targeting the PI3K/mTOR pathway. Cancer Lett. 2013; 329: 59-67.

79. Yang W, Shu M, Wang Y, Wang R, Hu Y, Meng L, Lin Z. 3D-QSAR and docking studies of 3-Pyridine heterocyclic derivatives as potent PI3K/mTOR inhibitors. J Mol Model. 2013; 1054-1055: 107-16.

80. Tsou HR, MacEwan G, Birnberg G, Grosu G, Bursavich MG, Bard J, Brooijmans N, Toral-Barza L, Hollander I, Mansour TS, Ayral-Kaloustian S, Yu K. Discovery and optimization of 2-(4-substituted-pyrrolo[2,3-b]pyridin-3yl)methylene- 4- hydroxybenzofuran- $3(2 \mathrm{H})$-o nes as potent and selective ATP-competitive inhibitors of the mammalian target of rapamycin (mTOR). Bioorg Med Chem Lett. 2010; 20: 2321-5.

81. Lv X, Ying H, Ma X, Qiu N, Wu P, Yang B, Hu Y. Design, synthesis and biological evaluation of novel 4-alkynylquinoline derivatives as PI3K/mTOR dual inhibitors. Eur J Med Chem. 2015; 99: 36-50.

82. Wu P, Su Y, Liu X, Zhang L, Ye Y, Xu J, Weng S, Li Y, Liu T, Huang S, Yang B, He Q, Hu Y. Synthesis and biological evaluation of novel 2-arylamino-3-(arylsulfonyl) quinoxalines as PI3Kalpha inhibitors. Eur J Med Chem. 2011; 46: 5540-8.

83. Wu P, Su Y, Guan X, Liu X, Zhang J, Dong X, Huang $\mathrm{W}, \mathrm{Hu} \mathrm{Y}$. Identification of novel piperazinylquinoxaline derivatives as potent phosphoinositide 3-Kinase (PI3K) Inhibitors. PLOS ONE. 2012; 7: e43171.

84. Mortensen DS, Perrin-Ninkovic SM, Harris R, Lee BG, Shevlin G, Hickman M, Khambatta G, Bisonette RR, Fultz KE, Sankar S. Discovery and SAR exploration of a novel series of imidazo[4,5-b]pyrazin-2-ones as potent and selective mTOR kinase inhibitors. Bioorg Med Chem Lett. 2011; 21: 6793-9.

85. Mortensen DS, Sapienza J, Lee BG, Perrin-Ninkovic SM, Harris R, Shevlin G, Parnes JS, Whitefield B, Hickman M, Khambatta G, Bisonette RR, Peng S, Gamez JC, et al. Use of core modification in the discovery of CC214-2, an orally available, selective inhibitor of mTOR kinase. Bioorg Med Chem Lett. 2013; 23: 1588-91.

86. Martinez Gonzalez S, Hernandez AI, Varela C, RodriguezAristegui S, Alvarez RM, Garcia AB, Lorenzo M, Rivero V, Oyarzabal J, Rabal O, Bischoff JR, Albarran M, Cebria A, et al. Imidazo[1,2-a]pyrazines as novel PI3K inhibitors. Bioorg Med Chem Lett. 2012; 22: 1874-8.

87. Martinez Gonzalez S, Hernandez AI, Varela C, RodriguezAristegui S, Lorenzo M, Rodriguez A, Rivero V, Martin JI, Saluste CG, Ramos-Lima F, Cendon E, Cebrian D, Aguirre E, et al. Identification of ETP-46321, a potent and orally bioavailable PI3K alpha, delta inhibitor. Bioorg Med Chem Lett. 2012; 22: 3460-6.

88. Alexander R, Balasundaram A, Batchelor M, Brookings D, Crepy K, Crabbe T, Deltent MF, Driessens F, Gill A, Harris 
S, Hutchinson G, Kulisa C, Merriman M, Mistry P, Parton T, Turner J, Whitcombe I, Wright S. 4-(1,3-thiazol-2-yl) morpholine derivatives as inhibitors of phosphoinositide 3-kinase. Bioorganic \& medicinal chemistry letters. 2008; 18: 4316-4320

89. Bengtsson M, Larsson J, Grigorios N, Peter S, Bailey JP, Griffen EJ, Arnould JC, Bird TGC. 5-heteroaryl thiazoles and their use as PI3K inhibitors . U.S. Patent 7,868,188B2, Jan, 11, 2011.

90. D'Angelo ND, Kim TS, Andrews K, Booker SK, Caenepeel S, Chen K, D'Amico D, Freeman D, Jiang J, Liu L, McCarter JD, San Miguel T, Mullady EL, et al. Discovery and optimization of a series of benzothiazole phosphoinositide 3-kinase (PI3K)/mammalian target of rapamycin (mTOR) dual inhibitors. J Med Chem. 2011; 54: 1789-811.

91. Liu KK, Zhu J, Smith GL, Yin MJ, Bailey S, Chen JH, Hu Q, Huang Q, Li C, Li QJ, Marx MA, Paderes G, Richardson $\mathrm{PF}$, et al. Highly Selective and Potent Thiophenes as PI3K Inhibitors with Oral Antitumor Activity. ACS Med Chem Lett. 2011; 2: 809-13.

92. Stec MM, Andrews KL, Booker SK, Caenepeel S, Freeman DJ, Jiang J, Liao H, McCarter J, Mullady EL, San Miguel T, Subramanian R, Tamayo N, Wang L, et al. Structureactivity relationships of phosphoinositide 3-kinase (PI3K)/ mammalian target of rapamycin (mTOR) dual inhibitors: investigations of various 6,5-heterocycles to improve metabolic stability. J Med Chem. 2011; 54: 5174-84.

93. Bruce I, Akhlaq M, Bloomfield GC, Budd E, Cox B, Cuenoud B, Finan P, Gedeck P, Hatto J, Hayler JF, Head D, Keller T, Kirman L, et al. Development of isoform selective PI3-kinase inhibitors as pharmacological tools for elucidating the PI3K pathway. Bioorg Med Chem Lett. 2012; 22: 5445-50.

94. Lin, H.; Erhard, K.; Hardwicke, M. A.; Luengo, J. I.; Mack, J.F.; McSurdy-Freed, J.; Plant, R.; Raha, K.; Rominger, C. M.; Sanchez,R.; Schaber, M. D.; Schulz, M.; Spengler, M. D.; Tedesco, R.; Xie, R.; Zeng, J. J.; Rivero, R. A. Synthesis and structure-activity relationships of imidazo[1,2-a] pyrimidin-5(1H)-ones as a novel series of beta isoform selective phosphatidylinositol 3-kinase inhibitors. Bioorg Med Chem Lett. 2012;22 (6):2230-234.

95. Sanchez R, Erhard K, Hardwicke MA, Lin H, McSurdyFreed J, Plant R, Kaushik R, Rominger C, Schaber M, Spengler M, Tedesco R, Rivero R. Synthesis and structure activity relationships of 1,2,4-triazolo[1,5-a]pyrimidin$7(3 \mathrm{H})$-ones as novel series of potent beta isoform selective phosphatidylinositol 3-kinase inhibitors. Bioorg Med Chem Lett. 2012; 22 (9): 3198-3202.

96. Lin H, Schulz MJ, Xie R, Zeng J, Luengo JI, Squire MD, Tedesco R, Qu J, Erhard, K.; Mack JF, Raha K, Plant R, Rominger CM et al. Rational Design, Synthesis, and SAR of a Novel Thiazolopyrimidinone Series of Selective PI3Kbeta Inhibitors. ACS Med Chem Lett. 2012; 3(7): 524-529.

97. Oka Y, Yabuuchi T, Fujii Y, Ohtake H, Wakahara S,
Matsumoto K, Endo M, Tamura Y, Sekiguchi Y. Discovery and optimization of a series of 2-aminothiazole-oxazoles as potent phosphoinositide 3-kinase gamma inhibitors. Bioorg Med Chem Lett. 2012; 22: 7534-8.

98. Peterson EA, Boezio AA, Andrews PS, Boezio CM, Bush TL, Cheng AC, Choquette D, Coats JR, Colletti AE, Copeland KW, DuPont M, Graceffa R, Grubinska B, et al. Discovery and optimization of potent and selective imidazopyridine and imidazopyridazine mTOR inhibitors. Bioorg Med Chem Lett. 2012; 22: 4967-74.

99. Morales GA, Garlich JR, Su J, Peng X, Newblom J, Weber K, Durden DL. Synthesis and cancer stem cell-based activity of substituted 5-morpholino-7H-thieno[3,2-b] pyran-7-ones designed as next generation PI3K inhibitors. J Med Chem. 2013; 56: 1922-39.

100. Ndubaku CO, Heffron TP, Staben ST, Baumgardner M, Blaquiere N, Bradley E, Bull R, Do S, Dotson J, Dudley D, Edgar KA, Friedman LS, Goldsmith R, et al. Discovery of 2-\{3-[2-(1-isopropyl-3-methyl-1H-1,2-4-triazol-5-yl) -5,6-dihydrobenzo[f] imidazo[1 ,2-d][1,4] oxazepin-9-yl]1H-pyrazol-1-yl -2-methylpropanamide (GDC-0032): a beta-sparing phosphoinositide 3-kinase inhibitor with high unbound exposure and robust in vivo antitumor activity. $\mathrm{J}$ Med Chem. 2013; 56: 4597-610.

101. Heffron TP, Heald RA, Ndubaku C, Wei BQ, Augistin M, Do S, Edgar K, Eigenbrot C, Friedman L, Gancia E,Jackson PS, Jones G, Kolesnikov A, et al. The Rational Design of Selective Benzoxazepin Inhibitors of the $\alpha$-Isoform of Phosphoinositide 3-Kinase Culminating in the Identification of (S)-2-((2-(1-Isopropyl-1H-1,2,4-triazol-5-yl)-5,6dihydrobenzo[f]imidazo[1,2-d][1,4]oxazepin-9-yl) oxy) propanamide (GDC-0326). J Med Chem. 2016; 59 (3): 985-1002

102. Staben ST, Blaquiere N, Tsui V, Kolesnikov A, Do S, Bradley EK, Dotson J, Goldsmith R, Heffron TP, Lesnick $\mathrm{J}$, Lewis C, Murray J, Nonomiya J, et al. Cis-amide isosteric replacement in thienobenzoxepin inhibitors of PI3-kinase. Bioorg Med Chem Lett. 2013; 23: 897-901.

103. Staben ST, Ndubaku C, Blaquiere N, Belvin M, Bull RJ, Dudley D, Edgar K, Gray D, Heald R, Heffron TP, Jones GE, Jones M, Kolesnikov A, et al. Discovery of thiazolobenzoxepin PI3-kinase inhibitors that spare the PI3-kinase beta isoform. Bioorg Med Chem Lett. 2013; 23 : 2606-13.

104. Certal V, Carry JC, Halley F, Virone-Oddos A, Thompson F, Filoche-Romme B, El-Ahmad Y, Karlsson A, Charrier V, Delorme C, Rak A, Abecassis PY, Amara C, et al. Discovery and optimization of pyrimidone indoline amide PI3Kbeta inhibitors for the treatment of phosphatase and tensin homologue (PTEN)-deficient cancers. J Med Chem. 2014; 57: 903-20.

105. Collier PN, Martinez-Botella G, Cornebise M, Cottrell KM, Doran JD, Griffith JP, Mahajan S, Maltais F, Moody CS, Huck EP, Wang T, Aronov AM. Structural basis for isoform selectivity in a class of benzothiazole inhibitors of 
phosphoinositide 3-kinase gamma. J Med Chem. 2015; 58: 517-21.

106. Gerspacher M, Fairhurst RA, Mah R, Roehn-Carnemolla E, Furet P, Fritsch C, Guthy DA. Discovery of a novel tricyclic 4H-thiazolo[5',4':4,5]pyrano[2,3-c]pyridine-2-amino scaffold and its application in a PI3Kalpha inhibitor with high PI3K isoform selectivity and potent cellular activity. Bioorg Med Chem Lett. 2015; 25: 3582-4.

107. Welker ME, Kulik G. Recent syntheses of PI3K/Akt/mTOR signaling pathway inhibitors. Bioorg Med Chem. 2013; 21: 4063-91.

108. Richard DJ, Verheijen JC, Yu K, Zask A. Triazines incorporating (R)-3-methylmorpholine are potent inhibitors of the mammalian target of rapamycin (mTOR) with selectivity over PI3Kalpha. Bioorg Med Chem Lett. 2010; 20: 2654-7.

109. Venkatesan AM, Chen Z, dos Santos O, Dehnhardt C, Santos ED, Ayral-Kaloustian S, Mallon R, Hollander I, Feldberg L, Lucas J, Yu K, Chaudhary I, Mansour TS. PKI-179: an orally efficacious dual phosphatidylinositol3-kinase (PI3K)/mammalian target of rapamycin (mTOR) inhibitor. Bioorg Med Chem Lett. 2010; 20: 5869-73.

110. Dehnhardt CM, Venkatesan AM, Chen Z, Delos-Santos E, Ayral-Kaloustian S, Brooijmans N, Yu K, Hollander I, Feldberg L, Lucas J, Mallon R. Identification of 2-oxatriazines as highly potent pan-PI3K/mTOR dual inhibitors. Bioorg Med Chem Lett. 2011; 21: 4773-8.

111. Peterson EA, Andrews PS, Be X, Boezio AA, Bush TL, Cheng AC, Coats JR, Colletti AE, Copeland KW, DuPont M, Graceffa R, Grubinska B, Harmange JC, et al. Discovery of triazine-benzimidazoles as selective inhibitors of mTOR. Bioorg Med Chem Lett. 2011; 21: 2064-70.
112. Kong DX, Yamori T. ZSTK474, a novel phosphatidylinositol 3-kinase inhibitor identified using the JFCR39 drug discovery system. Acta Pharmacol Sin. 2010; 31: 1189-97.

113. Rewcastle GW, Gamage SA, Flanagan JU, Frederick R, Denny WA, Baguley BC, Kestell P, Singh R, Kendall JD, Marshall ES, Lill CL, Lee WJ, Kolekar S, et al. Synthesis and biological evaluation of novel analogues of the pan class I phosphatidylinositol 3-kinase (PI3K) inhibitor 2-(difluoromethyl)-1-[4,6-di(4-morpholinyl)-1,3,5-triazin2-yl] -1H -benzimidazole (ZSTK474). J Med Chem. 2011; 54: 7105-26.

114. Wurz RP, Liu L, Yang K, Nishimura N, Bo Y, Pettus LH, Caenepeel S, Freeman DJ, McCarter JD, Mullady EL, Miguel TS, Wang L, Zhang N, et al. Synthesis and structure-activity relationships of dual $\mathrm{PI} 3 \mathrm{~K} / \mathrm{mTOR}$ inhibitors based on a 4-amino-6-methyl-1,3,5-triazine sulfonamide scaffold. Bioorg Med Chem Lett. 2012; 22: 5714-20.

115. Pinson JA, Zheng Z, Miller MS, Chalmers DK, Jennings IG, Thompson PE. L-Aminoacyl-triazine derivatives are isoform-selective PI3Kbeta inhibitors that target nonconserved Asp862 of PI3Kbeta. ACS Med Chem Lett. 2013; 4: 206-10.

116. Taha MO, Al-Sha'er MA, Khanfar MA, Al-Nadaf AH. Discovery of nanomolar phosphoinositide 3-kinase gamma (PI3Kgamma) inhibitors using ligand-based modeling and virtual screening followed by in vitro analysis. Eur J Med Chem. 2014; 84: 454-65. 